\title{
Geochemical distribution patterns as indicators for productivity and terrigenous input off NW Africa
}

\author{
K. Plewa*, H. Meggers, H. Kuhlmann, T. Freudenthal, M. Zabel, S. Kasten \\ University of Bremen, Department of Geosciences, PO Box 330440, 28334 Bremen, Germany
}

\section{A R T I C L E I N F O}

Article history:

Received 24 November 2011

Received in revised form

4 April 2012

Accepted 10 April 2012

Available online 25 April 2012

Keywords:

NW Africa

Canary Islands

Marine surface sediments

Geochemical tracers

Productivity

$\mathrm{Ba}$

Terrigenous input

\begin{abstract}
A B S T R A C T
One hundred and twenty-eight surface-sediment samples collected off North-West Africa were studied geochemically to detect the expressions of different meridional climate regimes and zonal productivity gradients in the surface sediments. This geochemical multi-tracer approach, coupled with additional information on the bulk carbonate and TOC contents makes it possible to characterise the sedimentological regime in detail. Typical terrigenous elements like $\mathrm{Al}, \mathrm{K}$ and $\mathrm{Fe}$ mirror the importance of the humid (fluvial) influence in the north of the study area and the dominance of aeolian input in the south. Furthermore, the distributions of Ti and Fe in the surface sediments serve as tracers for the supply of eolian volcanic material from the Canary Islands. The spatial variability of the TOC contents in the surface sediments closely follows the ocean surface productivity patterns, whereas the $\mathrm{CaCO}_{3}$ contents are mainly controlled by dilution with terrigenous matter. The potential productivity proxy Ba is not a reliable tracer for productivity in this region, since it is mainly supplied by terrigenous input (coupled with aluminosilicates).
\end{abstract}

(c) 2012 Elsevier Ltd. All rights reserved.

\section{Introduction}

The investigation area along the NW African continental margin extends from the Moroccan coast at about $33^{\circ} \mathrm{N}$ to the Mauritanian coast at about $18^{\circ} \mathrm{N}$ (Fig. 1, indicating the ocean surface current direction and the dominant wind systems). It covers the oligotrophic ocean waters of the North Atlantic subtropical gyre as well as the upwelling-influenced coastal waters off NW Africa. The sea floor morphology is characterised by a shallow continental shelf $(<150 \mathrm{~m})$ with greatest extension offshore to approximately $140 \mathrm{~km}$ north of Cape Blanc and lower extension to roughly $25 \mathrm{~km}$ at Cape Ghir and $75 \mathrm{~km}$ north of Cape Yubi (Summerhayes et al., 1976).

The southward directed Canary Current (CC, Fig. 1) is part of the Eastern Boundary Current System of the subtropical North Atlantic gyre (Mittelstaedt, 1991; Knoll et al., 2002). The CC flows southward over the continental shelf and slope along the coast (Stramma and Siedler, 1988; Mittelstaedt, 1991). Off Cape Blanc the CC starts to deflect to the west and at approximately $15^{\circ} \mathrm{N}$ the current diverges (Sarnthein et al., 1982; Fütterer, 1983). The dominant fraction of this surface water veers, driven by the Trade Winds, from the continental shelf to the open ocean. A minor portion of the waters from the CC continues south and southeast-wards along the African coast. The pattern of the Eastern

\footnotetext{
* Corresponding author. Tel.: +494146 913364; fax: +494146912081.

E-mail address: kplewa@uni-bremen.de (K. Plewa).
}

Boundary Current (EBC) is locally influenced by the presence of the islands, by the morphology of the shelf, the location of the shelf break and by variations in intensity and direction of local winds (Sarnthein et al., 1982). Mittelstaedt et al. (1975) described that occasionally enhanced southern monsoonal and other local winds can reverse the general direction of the surface water flow. This can cause the transport of warm tropical waters northward along the African coast as far as Cape Blanc.

The strong coastal upwelling regime in this region is driven by the interaction of the Northeast Trade Winds (NE Trades, Fig. 1) and the Canary Current (Mittelstaedt, 1991). The intensity of the upwelling along the Northwest African coast is linked to the seasonal variations of the Trade Winds which are generally correlated with the location of the Azores high-pressure system (Mittelstaedt, 1991). During summer the Azores High is situated at its northernmost position, and trade winds blow mainly between $32^{\circ} \mathrm{N}$ and $20^{\circ} \mathrm{N}$. In winter the Azores High is in its southernmost position with the trade wind belt located between $25^{\circ} \mathrm{N}$ and $10^{\circ} \mathrm{N}$. Thus, upwelling is constant throughout the year between $20^{\circ} \mathrm{N}$ and $25^{\circ} \mathrm{N}$, while north of $25^{\circ} \mathrm{N}$ upwelling occurs only in summer (e.g., Mittelstaedt, 1991). South of $20^{\circ} \mathrm{N}$ upwelling occurs primarily during winter. The described seasonality is most pronounced in this southern part of the region where Trade Winds are dominant in winter and spring and are replaced by the southwest monsoon winds during summer and autumn.

A characteristic feature of the upwelling zone is the formation of filaments, which transport the cooler upwelled water offshore (Van 


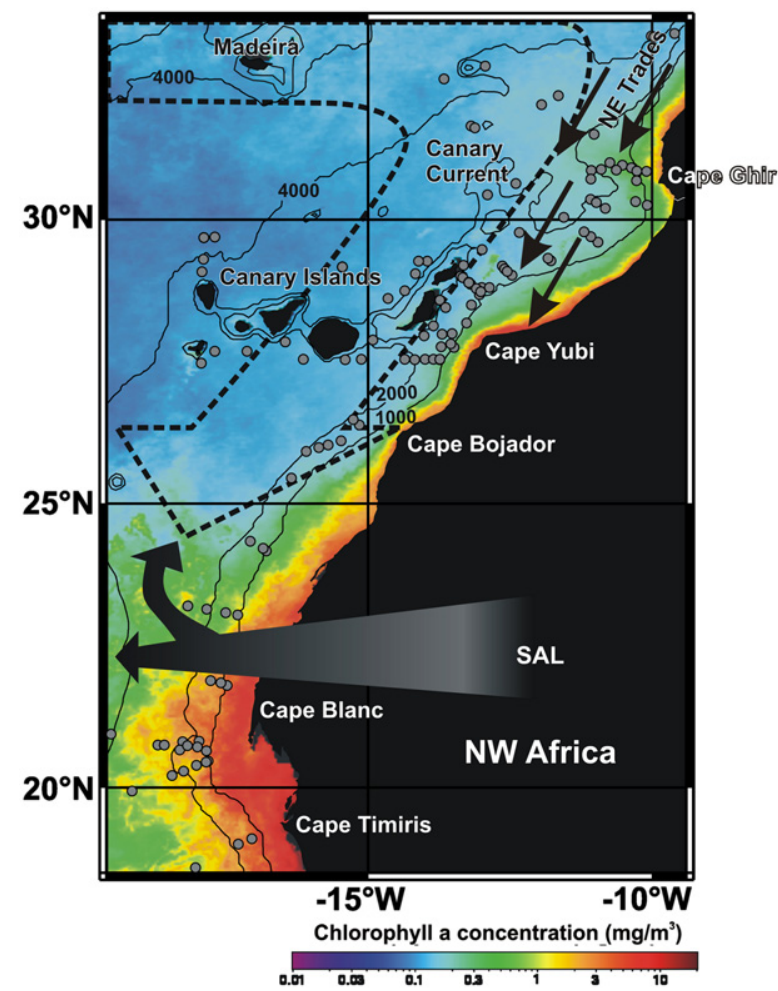

Fig. 1. Bathymetric map of northwest Africa with $1000 \mathrm{~m}, 2000 \mathrm{~m}$ and $4000 \mathrm{~m}$ depth contour lines. The grey circles show the locations of the surface samples used in this study. Dark arrows indicate the average positions of the present day dominant wind systems Northeast Trade winds (NE Trades) and Saharan Air Layer (SAL). The large black dashed arrow represents the average geostrophic current transport of the Canary Current (after Stramma and Siedler, 1988; Klein and Siedler, 1989). Included is the annual (2010) composite Chlorophyll concentration in the Canary Islands region as observed by MODIS Aqua (Feldman et al., 2012).

Camp et al., 1991; Nykjær and Van Camp, 1994). The development and growth of the larger, permanent filaments seems to be related to changes in topography such as headlands (Strub et al., 1991). Large filaments such as those found at Cape Ghir, Cape Yubi, Cape Bojador, Cape Blanc and Mauritania $\left(20.8^{\circ} \mathrm{N}\right)$ are observable as colder jets and meanders extending several hundreds of kilometres offshore (Van Camp et al., 1991; Nykjær and Van Camp, 1994; Barton et al., 1998; Davenport et al., 1999, 2002; Barton and Arístegui, 2004). Although upwelling occurs mostly on the shelf, these filaments play an important role in carbon cross-shelf transport and export to the deep ocean as has been described by Strub et al. (1991), Gabric et al. (1993) and Barton et al. (1998). However, the zone between $1000 \mathrm{~m}$ and $2000 \mathrm{~m}$ water depth represents the locus of maximum concentrations of biogenic particulate matter in the surface sediments (Fütterer, 1983).

Another important role for sedimentation in this area plays the input of dust, which is mainly controlled by the Northeast Trade Wind, the Saharan Air Layer (SAL) and the Harmattan (Sarnthein and Koopmann, 1980; Van Camp et al., 1991). Torres-Padrón et al. (2002) observed a seasonal pattern of Saharan dust events with maximum fluxes in winter and summer related to two dominant meteorological scenarios.

In boreal winter, dust events occur favoured by the southward displacement of the Intertropical Convergence Zone (ITCZ) and the weakening of the Azores High. Bergametti et al. (1989) detected dust transport from the Sahelian regions during this time. Trade winds are then well developed between latitudes $10^{\circ} \mathrm{N}$ and $25^{\circ} \mathrm{N}$ (Martinez et al., 1999). Additionally, very dry and warm winds (Harmattan) blow occasionally offshore from the
Sahara at latitudes between $15^{\circ} \mathrm{N}$ and $28^{\circ} \mathrm{N}$. These winds can carry desert dust into and over the ocean, although most of the time the boundary between the Harmattan and the maritime Trades is located over the continent parallel to the coast (Van Camp et al., 1991). In contrast, dust outbreaks which appear in boreal summer, favours dust transport from a northern source (Torres-Padrón et al., 2002). Due to the northward migration of the ITCZ to $\sim 19^{\circ} \mathrm{N}$ (Nicholson, 2000), trade winds blow further north between $20^{\circ} \mathrm{N}$ and $32^{\circ} \mathrm{N}$ (Martinez et al., 1999). The dust carried by the SAL originates from the southern Sahara and the adjacent Sahel zone (Koopmann, 1981; Sarnthein et al., 1982). This dust is then transported in a westerly direction. The SAL is divided into two branches, a northern one dispensing aeolian sediment over the northeast Atlantic Ocean and the Canary Islands, and a western branch transporting the aerosols far offshore (Fig. 1).

A further important source of terrigenous matter is the fluvial discharge of detrital material by northwest African rivers which is estimated to amount to a total of 110 million tons year ${ }^{-1}$ (Milliman and Meade, 1983; Hillier, 1995). In the northern part of the area, a number of seasonal rivers (e.g., the Souss at $30^{\circ} \mathrm{N}$ ) transport sediment derived from the Atlas and Anti-Atlas Mountain hinterland to the continental shelf and slope (Sarnthein et al., 1982; Wynn et al., 2000). Today, the major proportion of this fluvial material is deposited on the continental shelf. However, numerous canyons, dissecting the shelf break, provide conduits for shelf material that bypasses the continental slope and is deposited on the Seine Abyssal Plain, the Agadir Basin and Madeira Abyssal Plain (Weaver et al., 2000; Wynn et al., 2000). The canyon systems in the northern part of the NW African continent are still influenced by fluvial drainage (Ercilla et al., 1998; Wynn et al., 2000). Further to the south, on the western Saharan margin between $17^{\circ} \mathrm{N}$ and $28^{\circ} \mathrm{N}$, fluvial supply is significantly reduced compared to the area north of $29^{\circ} \mathrm{N}$ (Wynn et al., 2000). Here rivers and additional wadis reach the Atlantic Ocean only seasonally and, along the majority of the margin, there exists no significant fluvial input at all (Wynn et al., 2000).

The area along the NW African continental margin was chosen for investigation, because it comprises different climatic regimes, zonal productivity gradients and different geology of various source areas (Canary Islands, NW African continent) in a high spatial resolution. Our investigations cover an area reaching from Cape Ghir to Cape Timiris and comprise surface sediment samples from nearshore to offshore locations (spanning waterdepths of $355 \mathrm{~m}-4292 \mathrm{~m}$ ). Previous studies on geochemical and micro paleontological sedimentary parameters as well as on grain size distributions within the surface sediments have been conducted in this region (e.g., Meggers et al., 2002; Holz et al., 2004). In addition to previous studies, this study provides a highresolution overview and combination of parameters representing surface water productivity as well as input of terrigenous matter and related transport processes.

The study presented here is focussed on the clarification of two major problems: (1) Which geochemical parameter is the most reliable tracer for surface water productivity in the study area? (2) Which processes control the transport and distribution of terrigenous material originating from the adjacent NW African continent? To resolve the first problem (the most suitable surface productivity proxy), the spatial distribution of total organic carbon (TOC), calcium carbonate $\left(\mathrm{CaCO}_{3}\right)$, barium $(\mathrm{Ba})$ and the carbon/nitrogen ratio $(\mathrm{C} / \mathrm{N})$ in surface-sediments was analysed. The second problem (dominant terrigenous sediment provenance and transport processes) was approached by determining the distributions of aluminium $(\mathrm{Al})$, iron $(\mathrm{Fe})$, potassium $(\mathrm{K})$ and titanium (Ti) in the study area. 
Table 1

Selection of published $\mathrm{Ti} / \mathrm{Al}$ and $\mathrm{Fe} / \mathrm{Al}$ ratios.

\begin{tabular}{|c|c|c|c|}
\hline Material & Ti/Al ratio & $\mathrm{Fe} / \mathrm{Al}$ ratio & Reference \\
\hline Upper continental crust & 0.037 & 0.435 & (Taylor and McLennan, 1995) \\
\hline Upper continental crust & 0.040 & 0.399 & (Wedepohl, 1995) \\
\hline Average shale & 0.053 & 0.55 & (Wedepohl, 1971, 1995) \\
\hline Average shale & 0.059 & 0.61 & (Turekian and Wedepohl, 1961) \\
\hline River suspended matter & 0.060 & 0.51 & (Martin and Meybeck, 1979) \\
\hline Deep-sea clay & 0.060 & 0.63 & (Martin and Meybeck, 1979) \\
\hline Deep-sea clay & 0.059 & 0.83 & (Turekian and Wedepohl, 1961) \\
\hline Basalt average & 0.10 & 0.98 & (Vinogradov, 1962) \\
\hline Basaltic Rocks & 0.18 & 1.11 & (Turekian and Wedepohl, 1961) \\
\hline Morocco & - & 0.64 & (Guieu et al., 2002) \\
\hline Sahara & - & 0.69 & (Guieu et al., 2002) \\
\hline Dust $30^{\circ} \mathrm{N}, 11^{\circ} \mathrm{W}$ & 0.029 & 0.23 & (Stuut et al., 2005) \\
\hline Dust $28^{\circ} \mathrm{N}, 13^{\circ} \mathrm{W}$ & 0.060 & 0.51 & (Stuut et al., 2005) \\
\hline Dust $22^{\circ} \mathrm{N}, 17^{\circ} \mathrm{W}$ & 0.050 & 0.51 & (Stuut et al., 2005) \\
\hline Dust $19^{\circ} \mathrm{N}, 17^{\circ} \mathrm{W}$ & 0.070 & 0.45 & (Stuut et al., 2005) \\
\hline Moroccan dust & - & $0.99-1.24$ & (Bergametti et al., 1989) \\
\hline Sahelian dust & - & $1.51-1.76$ & (Bergametti et al., 1989) \\
\hline Tenerife & - & 0.7 & (Arimoto et al., 1995) \\
\hline Surface samples (Realm of the islands) & $0.09-0.25$ & $0.59-1.12$ & This study \\
\hline Surface samples (rest) & $0.05-0.09$ & $0.39-1.01$ & This study \\
\hline
\end{tabular}

\section{Materials and methods}

A total of 128 surface-sediment samples were recovered by multicorer and giant box corer during 8 cruises with RV Meteor (M37/1, M38/1, M42/4, M45/5, M53/1, M58/2), RV Victor Hensen (VH96/1) and RV Poseidon (PO272) from 1996 to 2003 (Neuer and participants, 1997; Fischer et al., 1998; Wefer et al., 1997, 1998; Neuer et al., 2000; Meggers et al., 2001, 2003; Bleil et al., 2004) (Fig. 1 and Table 1). For this study the upper $0-1 \mathrm{~cm}$ sample of each multicorer/giant box corer was used. These samples represent approximately 500 years in the open ocean and 100 or less years in the upwelling area (compare with Freudenthal et al. (2002), Henderiks et al. (2002); Meggers et al. (2002)). A Detailed overview of the sample positions are presented in Appendix 1. The related datasets are available at PANGAEA (http://doi.pangaea.de/10.1594/ PANGAEA.587452; http://doi.pangaea.de/10.1594/PANGAEA.587454).

\subsection{Geochemical analyses}

Prior to geochemical analyses, the sediment samples were first freeze-dried and then homogenised in an agate mortar and processed as described below.

\subsubsection{Total digestions}

Total digestion analyses were carried out with a microwave system (MLS, MEGA II). Each $50 \mathrm{mg}$ of the dried bulk sediment was placed together with a mixture of $3 \mathrm{ml}$ concentrated $\mathrm{HNO}_{3}(65 \%)$, $2 \mathrm{ml} \mathrm{HF} \mathrm{(47 \% )} \mathrm{and} 2 \mathrm{ml}$ concentrated $\mathrm{HCl}$ (30\%) of supra-pure quality into Teflon liners. After heating at a temperature of $\sim 200{ }^{\circ} \mathrm{C}$ under a pressure of $30 \mathrm{bar}$, the digested solutions were evaporated to near dryness and re-dissolved in $0.5 \mathrm{ml}$ concentrated $\mathrm{HNO}_{3}$ and $4.5 \mathrm{ml}$ deionised water (MilliQ). The solutions were placed back into the microwave system and homogenised. After cooling, the volume was made up to $50 \mathrm{ml}$ with $45 \mathrm{ml}$ deionised water. $\mathrm{Ba}, \mathrm{Al}, \mathrm{Fe}, \mathrm{K}$ and $\mathrm{Ti}$, the key elements of our study, were measured together with various major and minor elements by inductively coupled plasma optical emission spectrometry ICP-OES (Perkin Elmer, Optima 3300 R) with a cross-flow nebulizer (Perkin Elmer). For further information on analytical procedures refer to Zabel et al. (2001). Marine sediment reference standard MAG-1 (U.S. Geological Survey) was repeatedly digested. Measured values were within $5 \%$ of the certified ranges
(Gladney and Roelandts, 1987) as presented in detail in Appendix 2. Precision of ICP-AES analyses was better than $5 \%$ for the measured elements (also Appendix 2).

\subsubsection{Carbon and nitrogen analyses}

All carbon and nitrogen elemental analyses were done using a CHN-Analyser (Heraeus). Analytical standard deviation calculated for repeated measurements was $1.6 \%$ for carbon and $2.0 \%$ for nitrogen. The total carbon (TC) and total nitrogen (TN) contents were measured on untreated (non-acidified) samples. The total organic carbon content (TOC) was measured on samples that had been acidified in silver boats. Carbonate content was calculated using the difference of TC and TOC, assuming that calcium carbonate was the only carbonate-bearing mineral according to the formula: $\mathrm{CaCO}_{3}=((\mathrm{TC}-\mathrm{TOC}) \cdot 8.33)$.

The weight ratio of organic carbon/total nitrogen ( $\mathrm{C} / \mathrm{N}$ ratio) was employed to distinguish between the marine and the terrigenous fraction of organic carbon. TOC and calcium carbonate contents as well as the $\mathrm{C} / \mathrm{N}$ ratios of surface-sediment samples of cruises M37/1, M38/1, M42/4, M45/5 and VH96/1 (Appendix 1) were taken from Meggers (2002).

\subsection{Map generation}

To quantitatively assess the spatial continuity of the used data, for each data set a variogram analysis was conducted using software Surfer 8.0. The variogram analysis consists of the experimental variogram calculated from the data and the variogram model fitted to the data. The variogram model is selected from a set of mathematical functions that is fitted to the experimental variogram, because a continuous function is needed for kriging. The appropriate model was chosen by fitting the shape of the curve of the mathematical function to the experimental variogram. For more details the reader is referred to the Surfer User's Guide and the topic "Variogram Model Graphics" in the Surfer Help function.

By modelling appropriate variograms for all data sets, it was possible to find out whether a relationship between the different data points of one set exists and if it is therefore possible to create a contour map by using isopleths. Since for all data sets appropriate variogram models were obtained, we generated maps for the investigated data by using the gridding method of kriging. 


\section{Results and discussion}

\subsection{Major sediment components}

Deep-sea sediments are composed of variable mixtures of $\mathrm{SiO}_{2}$ (quartz/opal, silicates), $\mathrm{Al}_{2} \mathrm{O}_{3}$ (clay minerals, aluminosilicates) and $\mathrm{CaCO}_{3}$ (carbonates). To compare the relative portions of these major components off NW Africa, they are plotted in a triangular diagram (Fig. 2). Because no $\mathrm{SiO}_{2}$ data is available for the sample set of this study due to the sample preparation procedure, we used the $\mathrm{SiO}_{2}$ (and related $\mathrm{Al}_{2} \mathrm{O}_{3}$ and $\mathrm{CaCO}_{3}$ ) datasets of surface sediments at 17 other sites which are available from the study area (Wien et al., 2005; Wien et al., 2006); Schulz and Kölling, unpublished datasets). The datasets are available at PANGAEA, a detailed overview about their positions and the related references are given in Appendix 3.

Obviously most of the samples plot on the mixing line between average shale and marine carbonate (Fig. 2). Opal contents in the sediments are low, as samples with significantly higher biogenic silica concentration than average shale would plot closer to the $\mathrm{SiO}_{2}$ corner. This assumption is supported by the investigations of Neuer et al. (1997) who observed on average very low opal contents in this region.

Since we assume that a significant dilution of the terrigenous fraction by silicious organisms can be ruled out, we propose that distribution is mainly influenced by dilution with carbonate. Therefore $\mathrm{Fe}, \mathrm{K}$ and Ti have been normalised to $\mathrm{Al}$ to reveal subtle changes in the chemical composition of the sediments, which are not caused by dilution with $\mathrm{CaCO}_{3}$. This representation should indicate a better identification of the different source regions, transport pathways, weathering conditions in the source area or the different climatic regions.

\subsection{Productivity related sediment compounds}

\subsubsection{Organic matter and $\mathrm{C} / \mathrm{N}$ ratio}

The spatial variability of the TOC contents within the surface sediments in the region of the Canary Islands shows a zonal gradient with highest values at the capes and low values in the open ocean (Fig. 3(A)). Highest amounts of preserved TOC (2.9\%) are observable off Cape Blanc, whereas sediments off Cape Ghir show elevated TOC

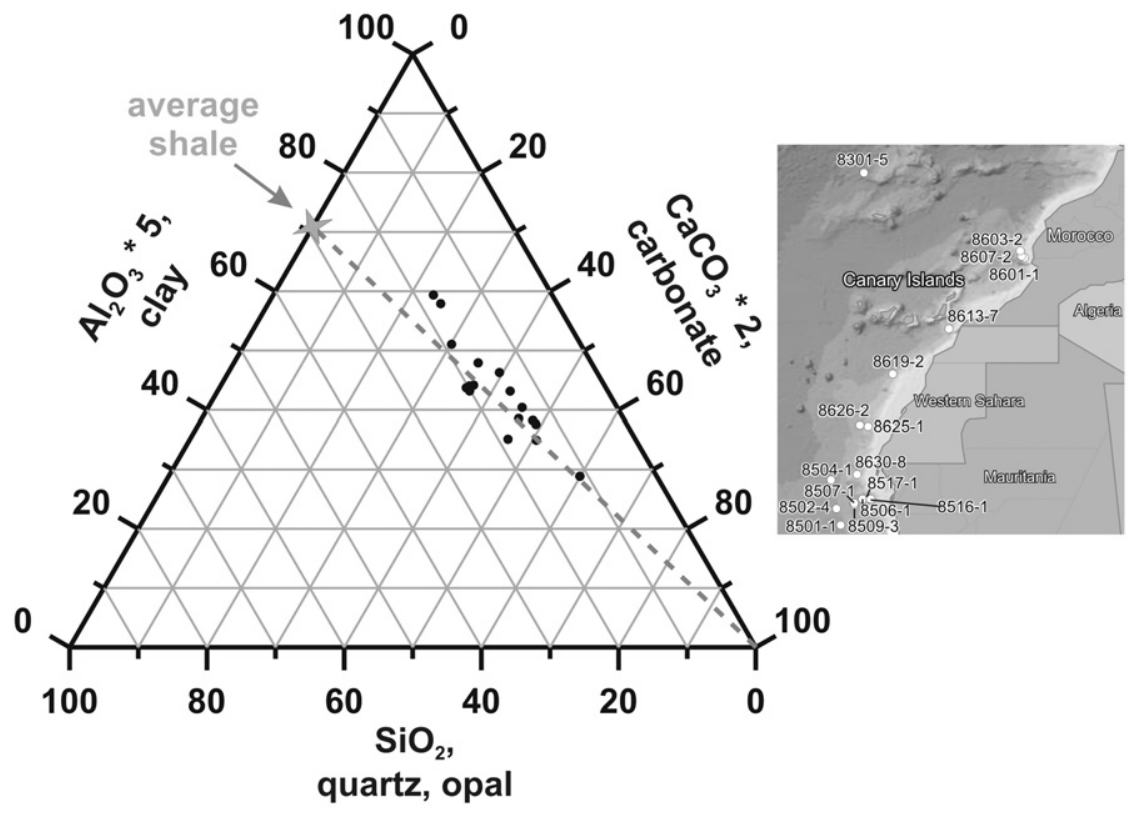

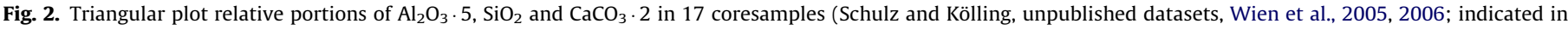
Appendix 3). Samples which plot on the line average shale $-\mathrm{CaCO}_{3}$ two represent a binary mixture between clay and carbonate.
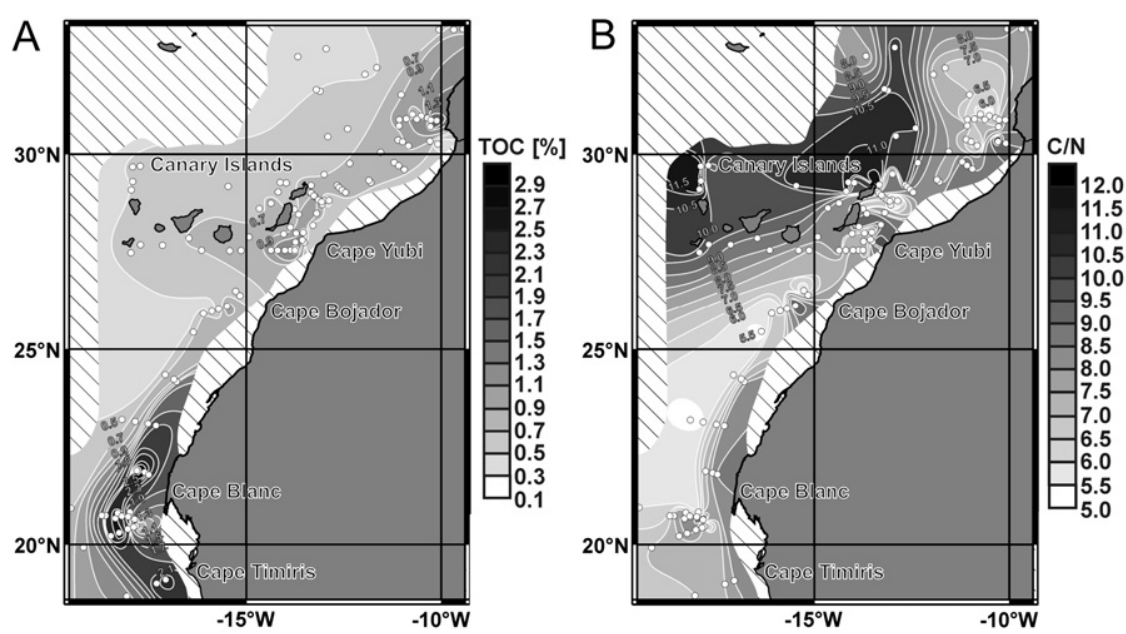

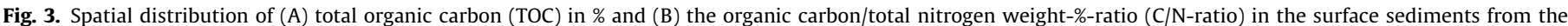
Canary Islands region. 
contents of up to $1.9 \%$. Lower values are found off Cape Yubi (1.6\%) and off Cape Bojador (1.0\%). The lowest TOC contents $(<0.5 \%)$ are observed offshore. It is also obvious that slightly lower TOC values are reached alongshore between the capes with lowest TOC contents between Cape Yubi and Cape Ghir ( $<0.7 \%$ ).

The amount of organic matter which is preserved in marine sediments depends mainly on the quantity, quality and seasonality of primary production, on water column depth, sedimentation rate, on redox conditions in the water column and the sediment, on remineralisation processes and microbial activity (e.g., Zonneveld et al., 2010 and references therein). This raises the question if the observed zonal gradient of TOC contents (Fig. 3(A)) mirrors mainly surface water primary production, preservation and/or remineralisation processes or lateral advection.

Surface water primary productivity off NW Africa reveals a great spatial variability as indicated by satellite-derived pigment data (Van Camp et al., 1991; Davenport et al., 1999, Fig. 1), trap data (e.g., Davenport et al., 1999, 2002; Neuer et al., 2002) and as shown in several studies (e.g., García-Muñoz et al., 2004 and references therein; Eberwein and Mackensen, 2006). Thereby highest production occurs under upwelling conditions mainly on the African shelf and is most pronounced around the capes, especially at Cape Blanc which shows the highest amounts of primary productivity (Fig. 1). The capes are sites of filament formation. These filaments play an important role in the export of cold, nutrient-rich water and substantial amounts of biomass offshore into the oligotrophic NE Atlantic. It is expected that the TOC content of the underlying surface sediments will reflect the upwelling-induced primary production in the surface water as well as the export of the upwelling signal towards the open ocean through these filaments.

The spatial variability of the sedimentary TOC content of the Canary Islands region (Fig. 3(A)) reflects in most parts the surface water primary production. Generally, TOC content decreases with increasing water depth (Fig. 3(A) and Fig. 4). Increased preservation due to higher sedimentation rates and higher supply of

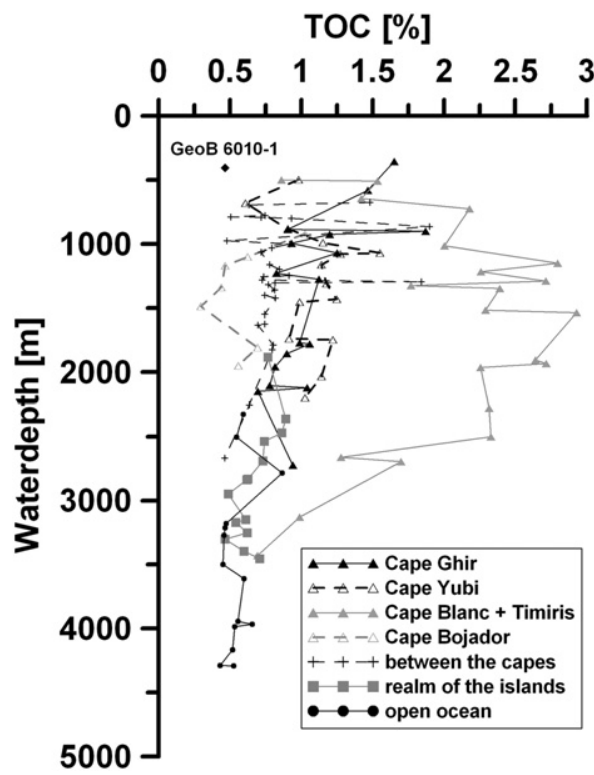

Fig. 4. Plot of total organic carbon (TOC) concentrations versus water depth Four major domains in the study area are shown with different symbols: triangles for the capes, which are influenced by upwelling and filament formation (filled black: Cape Ghir, non filled black: Cape Yubi, filled grey: Cape Blanc/Timiris, non filled grey: Cape Bojador), crosses for the area between the capes, squares for the locations in the realm of the islands and dots for the subtropical open ocean. GeoB $6010-1$ is shown separately, because it is possibly turbidite influenced (Meggers et al., 2002) organic matter at the upwelling-influenced sites are likely to explain this relationship as described in detail by Müller and Suess (1979). Additionally, water depth plays an important role for organic matter degradation. Particle-associated bacteria degrade organic compounds from sinking particles, leading to the production of dissolved OM (Honjo et al., 2008 and references therein), while breaking the sinking particles into smaller, suspended OM, thus reducing the overall organic matter particle flux and inducing compositional changes.

Off Cape Blanc, almost permanent upwelling prevails and "giant filaments" (Schemainda et al., 1975; Mittelstaedt, 1991; Van Camp et al., 1991; Nykjær and Van Camp, 1994) leading to the highest chlorophyll concentrations in the surface water (Fig. 1). Since the highest amounts of TOC are observed in the underlying sediments (Fig. 3(A)), it is obvious that the productivity signal of the surface water is well reflected here. This linear relationship between the marine productivity and the TOC contents in surface sediments is also apparent off the other cape regions. Especially off Cape Yubi, the influence of the filament system with its offshore limit of around $16^{\circ} \mathrm{W}$ southeast of Tenerife is traced by the composition of the underlying sediments. The sites between the capes reveal relatively low TOC contents despite shallow water depths. This corresponds with relatively lower productivity as recorded by lower chlorophyll concentrations compared to the capes. Therefore, we conclude in accordance with Meggers et al. (2002) that the spatial TOC distribution in the surface sediments in the Canary Islands region is mainly influenced by the variability of organic matter supply. But other processes like variations in upwelling intensity and lateral advection due to differences in morphology, leading to the observed differences between the capes, should not be disregarded.

Although production is highest on the shelf, generally higher sedimentary TOC contents are measured on the slope of the NW African margin (Fig. 3(A) and Fig. 4). This distribution pattern is on the one hand a result of the described shift of the upwelling signal towards the open ocean through filaments and on the other hand brought about by re-deposition of shelf material. Shelf sediment resuspension and subsequent lateral advection of the particulate matter offshore result in this low accumulation of upwellinginduced material on the shelf and higher sedimentation on the slope between water depths of about $1000 \mathrm{~m}$ and $2000 \mathrm{~m}$ (Fütterer, 1983). Solely at Cape Ghir highest TOC contents are reached at shallower water depths between $\sim 350 \mathrm{~m}$ and $900 \mathrm{~m}$.

The Canary Islands region is affected by regular input of atmospheric dust which is a possible source of additional terrigenous organic particles to the investigated sediments (Huang et al., 2000; Eglinton et al., 2002; Formenti et al., 2003; Schefuß et al., 2003). Therefore, the marine and the terrigenous fractions have to be distinguished when applying TOC as a marine productivity proxy (Wagner and Dupont, 1999). This distinction is also very important for the evaluation of TOC preservation, because shifts in the relative importance (terrestrial versus marine) of the particulate organic matter (OM) flux at the sediment surface may influence the OM reactivity and degradation in sediments. The general perception is that sediments dominated by terrestrial inputs can be expected to be less reactive than sediments that contain mostly autochthonous algal OM (e.g., Zonneveld et al., 2010 and references therein). For this purpose, the organic carbon/total nitrogen weight-\%-ratios (henceforth referred to as $\mathrm{C} / \mathrm{N}$ ratios) of the surface sediment samples were determined. For decades the $\mathrm{C} / \mathrm{N}$ ratio has been used as a parameter for the evaluation of the relative influence of terrestrial and marine organic matter in several ecosystems (Bordovskiy, 1965b; Tyson, 1995). High-molecular-weight plant organic matter (e.g., lignin etc.) contains lower amounts of nitrogen and thus has a $\mathrm{C} / \mathrm{N}$ ratio of 20 and greater (Meyers, 1994). Therefore, high $\mathrm{C} / \mathrm{N}$ ratios in sediments indicate a 
contribution of terrigenous organic matter (Faganelli et al., 1988). Phytoplankton which is the main organic matter producer in the surface ocean is relatively rich in proteins and shows average $\mathrm{C} / \mathrm{N}$ ratios of 6 as stated by Bordovskiy (1965a). Hence, low sedimentary $\mathrm{C} / \mathrm{N}$ ratios indicate a dominance of marine organic matter. However, the use of $\mathrm{C} / \mathrm{N}$ as an indicator for terrestrial organic matter should be used carefully, because of the preferential diagenetic remineralisation of nitrogen compared to organic carbon (Emery and Uchupi, 1984), the amount of inorganic nitrogen bound in clay minerals (Müller, 1977) and the preferential uptake of nitrogen by benthic organisms that lead to an increase of the $\mathrm{C} / \mathrm{N}$ ratio during burial. Since in the study area the determined $\mathrm{C} / \mathrm{N}$ ratios are generally low (Fig. 3(B)), these processes seem to play only a secondary role.

The $\mathrm{C} / \mathrm{N}$-ratio varies between 5 and 12 (Fig. 3(B)), indicating a dominance of marine organic matter. The lowest ratios observed, between 5 and 6, were from offshore south of the Canary islands, southeast of Lanzarote and off Cape Ghir. Generally higher $\mathrm{C} / \mathrm{N}$-ratios are found in the realm of the islands with maximum ratios north of La Palma and northeast of Lanzarote. This observation points to a slightly higher contribution of terrigenous organic matter in this offshore region north of the islands. Although the sediments close to the NW African coast also display slightly higher $\mathrm{C} / \mathrm{N}$ ratios (between 8 and 9), we assume in accordance with (Stein, 1991), who reported that $\mathrm{C} / \mathrm{N}$ ratios lower than 10 point to a strict marine origin, that a significant influence of terrigenous organic matter can be excluded. This conclusion is supported by $\delta^{13} C_{\text {org }}$ values determined for the study area by Meggers et al. (2002) which also point to a strict marine origin.

Overall, a gradient from higher TOC contents nearshore to lower TOC contents offshore is observed and is in agreement with surface water productivity patterns (Fig. 1). This is due to the interaction of the highest primary production and the highest sedimentation rates nearshore - especially off the capes - leading to a good preservation of the productivity signal (Tyson, 2001). Offshore, the opposite trend is evident. Here, low primary production coupled with low sedimentation rates leads to the observed lowest TOC contents due to a high degree of degradation of organic matter (Jung et al., 1997). However, the TOC contents of the shelf sediments are an exception. Although here the overall highest amount of surface water primary production occurs, the TOC contents are slightly lower in comparison to the slope sediments. It is supposed that this discrepancy is a result of resuspension and lateral advection processes occurring in the area.

An important result is that even though the study area is subject to a high input of terrigenous material, organic matter of terrestrial origin is not delivered to the seafloor in significant amounts. This outcome agrees with previous investigations of Meggers et al. (2002) who examined geochemical proxies (TOC, carbonate, $\delta^{15} \mathrm{~N}, \delta^{13} \mathrm{C}_{\mathrm{org}}$, $\mathrm{C} / \mathrm{N}$-ratio) and micropaleontological parameters (diatoms, dinoflagellates, foraminifera, pteropods). Furthermore, a good correlation between alkenone and TOC contents as determined for core GeoB 5546-2 nearshore off Cape Yubi (Meggers et al., unpublished data) suggests a terrigenous TOC fraction to be negligible in this region.

\subsubsection{Carbonate}

In contrast to the TOC distribution the carbonate contents are lowest in the vicinity of the capes and offshore south of the Canary Islands, while the highest contents are observed in the open ocean north of the islands (Fig. 5). In the entire study area carbonate contents range from minimum values of $14.9 \mathrm{wt} \%$ (GeoB 7932) off Cape Timiris up to maximum values of $71.7 \mathrm{wt} \%$ (GeoB 5561) in the open ocean north of the islands. The observed carbonate distribution pattern in the study area could be a result of dissolution processes in the water column and/or in the sediment as well as by dilution with terrigenous matter.

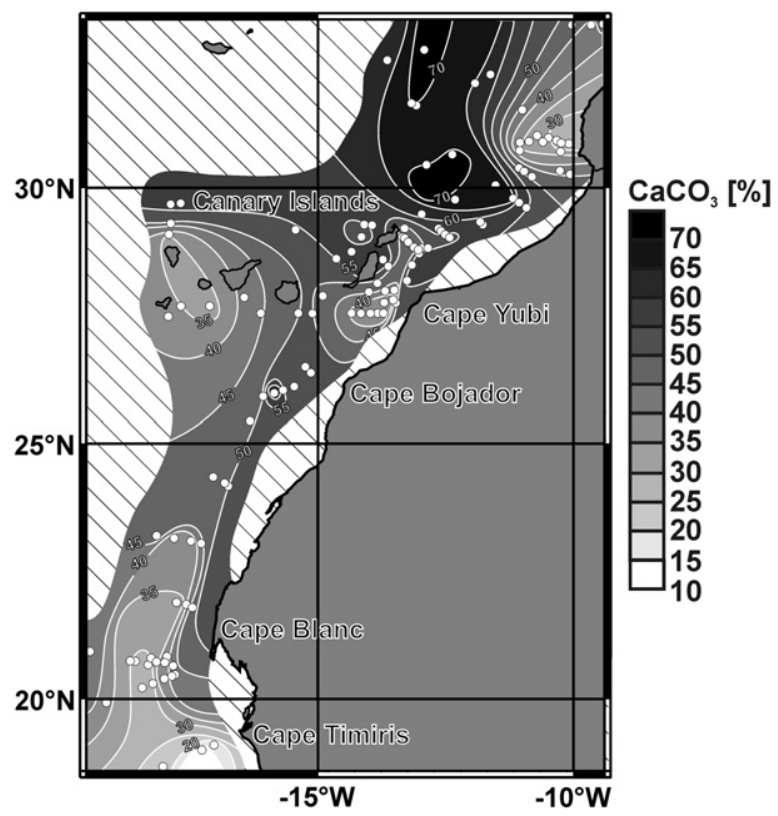

Fig. 5. Spatial distribution of the carbonate concentration in $\%$ in the surface sediments from the Canary Islands region.

\subsubsection{Dilution}

As the lowest carbonate values (Fig. 5) correspond to the highest aluminium contents (Fig. 9), dilution by a varying supply of terrigenous material should be considered as the most important factor responsible for the observed $\mathrm{CaCO}_{3}$ distribution pattern. A statistical test by comparing all pairs using TukeyKramer identified that two regions are significantly different: north of Cape Ghir to Cape Yubi and Cape Bojador to Cape Timiris. Therefore carbonate and aluminium contents of the samples from these different groups were tested for their linear association. Relatively good correlation coefficients $\left(R^{2}\right)$ were found for the inverse correlation of both components $(0.78$ for samples north of Cape Ghir to Cape Yubi and 0.67 for samples off Cape Bojador to Cape Timiris). The significances of the regressions were tested using a lack of fit test (Sall et al., 2005). The related $p$-Values (95\% confidence) in the statistical lack of fit test exceed the critical value of 0.05 indicating a linear relationship between both components in both regions. This result agrees with the conclusion of other authors (e.g., Hays and Peruzza, 1972; Diester-Haas, 1976; Shimmield, 1992; Matthewson et al., 1995; Bozzano et al., 2002; Moreno et al., 2002). The observed differences between the sample sets north and south of Cape Bojador can be related to the existence of another important mineral phase, most likely quartz. This assumption is supported by Fig. 2 as well as by investigations of Holz et al. (2004) who observed increases in grain size towards the south of the region.

\subsubsection{Dissolution}

Although dilution by terrigenous material was shown to have the main influence on the carbonate distribution pattern, an additional impact by dissolution should be considered.

Carbonate particles appear to be well preserved during settling through the water column (Berger et al., 1982). Thus, the carbonate flux to the sediment corresponds approximately to the production of carbonate particles in the upper ocean. However, only about 60\% of the global planktonic carbonate export flux accumulate on continental slopes and the deep-sea (Milliman, 1993). The dissolution of carbonate microfossils after and during deposition is supposed to have the main influence on the primary productivity 
pattern. Calcium carbonate dissolution is controlled by three major factors. First, the degree of undersaturation of the sea water with respect to calcite and aragonite, second, the reaction with respiratory $\mathrm{CO}_{2}$ produced during aerobic degradation of organic matter and third, the time the carbonate particles are exposed to sea water (dependent on sedimentation rate) provided that it is undersaturated with respect to calcite/aragonite.

Following Berger (1967), Peterson (1966), Adelseck and Berger (1975) and Honjo (1977), it is assumed that the observed carbonate distribution pattern in the study area is not affected by dissolution of calcite in the water column. Additionally, all sample locations are situated well above the calcite lysocline which is positioned in the eastern basin of the North Atlantic $\left(20-40^{\circ} \mathrm{N}\right)$ at a water depth of around $5000 \mathrm{~m}$ (Broecker and Takahashi, 1978). Aragonite dissolution within the water column should also have only a minor influence on sedimentary carbonate contents since $>80 \%$ of the investigated samples are located above the expected aragonite lysocline, which lies 1-2 km above the calcite lysocline (Berger, 1968).

Because carbonate dissolution within the water column can mostly be excluded, dissolution within the sediment, respectively at the sediment-water interface, has to be taken into account as being potentially responsible for the observed spatial distribution of $\mathrm{CaCO}_{3}$ contents. Various studies suggest aerobic organic matter degradation as the most likely cause for calcite dissolution in supralysoclinal sediments as well as sediments located below high-productivity regions (e.g., Reichart et al., 1997; Pfeifer et al., 2002; Volbers and Henrich, 2002; de Villiers, 2005). A regression analysis of TOC versus carbonate suggests that a linear model does not fit well $\left(R^{2}=0.41\right.$ and $p$-Value $95 \%$ confid $\left.<0.05\right)$. Therefore a significant correlation between aerobic TOC mineralization and carbonate distribution can be rejected. This can be also observed when comparing the distribution pattern of both compounds (Fig. 3(A) and Fig. 5).

Therefore we conclude that the carbonate content of the investigated sediments is mainly controlled by dilution with terrigenous matter.

\subsubsection{Barium}

The barium/aluminium ratios $(\mathrm{Ba} / \mathrm{Al})$ range between 0.0052 and 0.0127 (Fig. 9). The distribution pattern of the $\mathrm{Ba} / \mathrm{Al}$ ratio of the surface sediments shows a zonal gradient with lowest values nearshore and highest values in the open ocean (Fig. 6). The $\mathrm{Ba} / \mathrm{Al}$ value reaches its maximum offshore Cape Ghir.

Biogenic barium has been proposed as a geochemical paleoproductivity proxy which - in certain ocean areas - has significant advantages over the traditional biogenic sediment compounds calcium carbonate, organic carbon and opal. A variety of studies has established a relationship between the marine geochemistry of barium and ocean surface water productivity (e.g., Goldberg and Arrhenius, 1958; Dehairs et al., 1980; Bishop, 1988; Dymond et al., 1992; Gingele and Dahmke, 1994; Klump et al., 2001). Fluxes of barium and organic matter, based on sediment trap data of different oceanic regions have been used to develop algorithms, which link the barium flux to export production (Dymond et al., 1992; Francois et al., 1995; Nürnberg et al., 1997). Solid phase barium - or more precisely biogenic barite - may therefore be used to trace changes in recent and past primary production (e.g., Gingele and Dahmke, 1994; Francois et al., 1995; Ganeshram et al., 1995; Paytan et al., 1996; Ganeshram and Pedersen, 1998; Kasten et al., 2001; Pfeifer et al., 2001). However there are limiting factors which impact on the application of $\mathrm{Ba}$ as a productivity tracer. While the application of $\mathrm{Ba}$ is well established for openocean settings (Thompson and Schmitz, 1997; Gingele et al., 1999), several problems exist for nearshore areas. First, the linkage

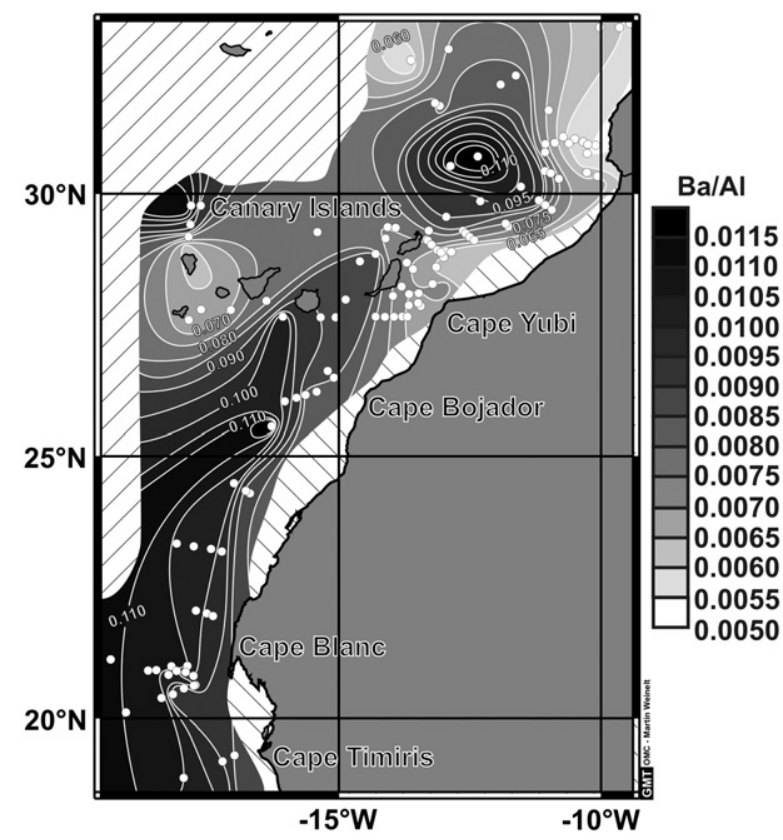

Fig. 6. Spatial distribution of the barium/aluminium $(\mathrm{Ba} / \mathrm{Al})$ ratios in the surface sediments from the Canary Islands region.

between particulate Ba and organic carbon is poorly constrained for these areas as shown by sediment and trap geochemical signatures (Francois et al., 1995; Fagel et al., 1999; Dehairs et al., 2000). The lateral transport of refractory organic matter and/or resuspended barite from the continental shelf inhibits accurate estimations of export production. Second, according to Dymond et al. (1992), Von Breymann et al. (1992) and Klump et al. (2000), water depth also is a crucial factor in the generation of barite crystals. This is because the deeper the water the more time is available for barite precipitation within aggregates sinking through the water column. Generally, at least $1000 \mathrm{~m}$ water depth are assumed to be required for the Ba productivity signal to fully develop (Von Breymann et al., 1992).

As has been discussed above the TOC content of the surface sediments well reflects productivity conditions in the overlying surface waters and is therefore assumed to be a reliable productivity tracer in the study area (cf Section 3.2.1). A relationship between the distribution pattern of TOC and the $\mathrm{Ba} / \mathrm{Al}$ ratios in the investigated surface sediments is not observed (Fig. 3(A) and Fig. 6) as is also supported by a lack of correlation between TOC and Ba (the statistical test reveals an $R^{2}=0.25$ and a $p$-Value $95 \%$ confid. significantly below 0.05). Based on these findings we suggest that the suitability of $\mathrm{Ba}$, respectively $\mathrm{Ba} / \mathrm{Al}$, as a productivity proxy is limited in this region. We assume that this limitation is mainly based on two different facts: (1) barium is mainly discharged by terrigenous material in this region as discussed in detail by e.g., (Plewa et al., 2006); and/or (2) barite precipitation in the water column is strongly influenced by the variable water depths of the studied sediments (e.g., Von Breymann et al., 1992; Klump et al., 2000).

The reason for the increase of Ba with increasing water depth could possibly be explained by either the longer sinking duration potentially providing more time for barite precipitation within the water column or resuspension, lateral transport and redistribution processes. However, the coupling of $\mathrm{Ba}$ with the terrigenous material should also be considered to be responsible for the observed decoupling between $\mathrm{TOC}$ and $\mathrm{Ba} / \mathrm{Al}$ and will be discussed in the following. 
Barium is also contained in other particulate phases within the sediment - these being diagenetic barite, Ba associated with carbonates (e.g., foraminifera shells), Ba associated with $\mathrm{Mn} / \mathrm{Fe}$ oxides and hydroxides and Ba adsorbed onto and/or incorporated into aluminosilicates (terrigenous Ba), as described by Gingele and Dahmke (1994) and Zonneveld et al. (2010). Since the sedimentation in the study area is highly influenced by the input of terrigenous matter through dust, we expect that a significant fraction of the bulk Ba content is of lithogenic origin. This assumption is supported by the positive correlation between bulk Ba contents and $\mathrm{Al}$ contents as shown in Fig. 7. All samples are located between the dilution lines of average shale (Wedepohl, 1971, 1995) and continental crust (Taylor, 1964).

To differentiate between excess barium $\left(\mathrm{Ba}_{\mathrm{xs}}\right)$, representing biogenic and diagenetic barite, $\mathrm{Ba}$ associated with carbonates as well as $\mathrm{Ba}$ associated with $\mathrm{Mn} / \mathrm{Fe}$ oxides and hydroxides, and terrigenous barium $\left(\mathrm{Ba}_{\text {lith }}\right)$, we used the following normative calculations:

$\left[\mathrm{Ba}_{\mathrm{xs}}\right]_{\mathrm{g} / \mathrm{kg}}=\left[\mathrm{Ba}_{\mathrm{tot}}\right]_{\mathrm{g} / \mathrm{kg}}-\left(\mathrm{Ba} / \mathrm{Al}_{\text {lith }}\right) \cdot\left[\mathrm{Al}_{\mathrm{tot}}\right]_{\mathrm{g} / \mathrm{kg}}$

and

$\left[\mathrm{Ba}_{\text {lith }}\right]_{\mathrm{g} / \mathrm{kg}}=\left[\mathrm{Ba}_{\mathrm{tot}}\right]_{\mathrm{g} / \mathrm{kg}}-\left[\mathrm{Ba}_{\mathrm{xs}}\right]_{\mathrm{g} / \mathrm{kg}}$

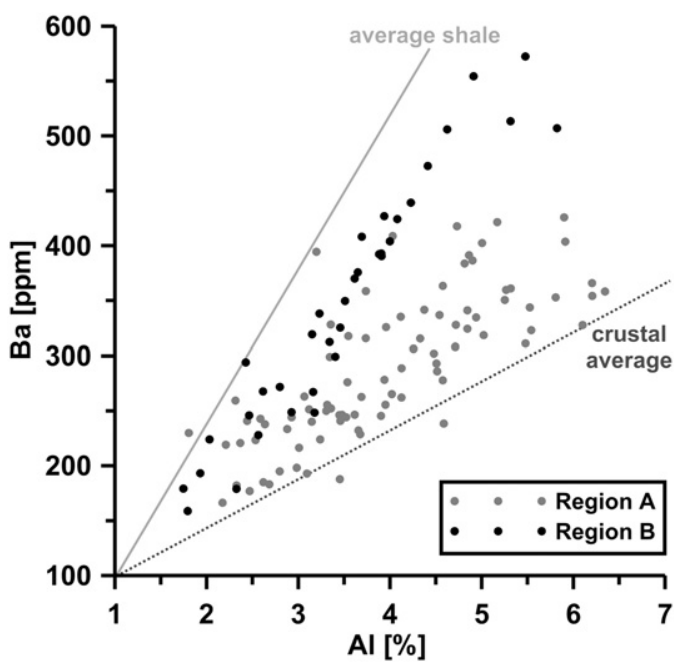

Fig. 7. Cross-plot of barium contents [ppm] versus aluminium concentrations [\%]. Included are the dilution lines of average shale (Wedepohl, 1971, 1995) and of the crustal average (Taylor, 1964). The correlation coefficients $\left(R^{2}\right)$ are 0.66 for region A (north of Cape Ghir-Cape Yubi) and 0.92 for region B (Cape Bojador-Cape Timiris). The significant difference of both regions has been statistically tested by comparing all pairs using Tukey-Kramer HSD. where $\mathrm{Ba}_{\text {lith }}$ represents the terrigenous barium, $\mathrm{Al}_{\text {tot }}$ is the total $\mathrm{Al}$ in the sediment, $\mathrm{Ba} / \mathrm{Al}_{\text {lith }}$ is the terrigenous $\mathrm{Ba} / \mathrm{Al}$ ratio, $\mathrm{Ba} \mathrm{xs}_{\mathrm{xs}}$ is the excess barium, and $\mathrm{Ba}_{\text {tot }}$ is the total $\mathrm{Ba}$ content of the sediment samples.

The $\mathrm{Ba} / \mathrm{Al}$ ratio is usually derived from the average crustal composition varying between 0.005 and 0.01 (e.g., Turekian and Wedepohl, 1961; Wedepohl, 1971; Rösler and Lange, 1972; Wedepohl, 1995). However, the usage of such a Ba/Al ratio potentially introduces substantial errors into the determination of $\mathrm{Ba}_{\mathrm{xs}}$ as shown by Reitz et al. (2004). Therefore, we decided to use two different $\mathrm{Ba} / \mathrm{Al}$ ratios based on the lowest detected value in the sub-regions, assuming that these ratios approximately represent the regional detrital background values. For samples situated in the northern part of the study area (north of Cape Ghir to Cape Yubi, in the following: region $\mathrm{A}$ ) we applied a $\mathrm{Ba} / \mathrm{Al}$ ratio of $0.0052(\mathrm{Ba} / \mathrm{Al}$ ratios are in the range of 0.0052-0.0127). For samples located in the region between Cape Bojador and Cape Timiris (region B) the average shale value of 0.0073 (Wedepohl, 1971) is appropriate for calculating $\mathrm{Ba}_{\mathrm{xs}}$, since $\mathrm{Ba} / \mathrm{Al}$ ratios vary between 0.0077 and 0.0121 . The significant difference (also statistically verified with an "Oneway Anova" test after Sall et al., 2005) between the $\mathrm{Ba} / \mathrm{Al}$ ratios of the two regions is easily explained by the differences in the geology of the corresponding hinterland and the different transport pathways of lithogenic material being related to climatic differences as well as to different wind-systems. The difference between the source regions and accordingly the provenance of the lithogenic material will be discussed in the following section in more detail.

Barium associated with aluminosilicates $\left(\mathrm{Ba}_{\mathrm{lith}}\right)$ is the dominant fraction in both regions (Fig. 8). The average percentage of $\mathrm{Ba}_{\mathrm{xs}}$ is $\sim 29 \%$ in region $A$ and $\sim 25 \%$ in region $B$. Solely within region A two sites (GeoB 4216 and GeoB 4217) show a dominance of the $\mathrm{Ba}_{\mathrm{xs}}$ fraction. This leads to the assumption that here the Ba content of the surface sediment could reflect the surface water productivity related to the Cape Ghir filament. This result is in accordance with findings of Moreno et al. (2002). These authors concluded that at site GeoB 4216 the $\mathrm{Ba}_{\mathrm{xs}}$ record is a reliable indicator of (paleo-)productivity changes related to the Cape Ghir filament.

We conclude that the Ba content of the surface sediments in the region of the Canary Islands mainly reflects the input of Ba adsorbed onto and/or incorporated into aluminosilicates. This finding is in accordance with the results of a study based on a sediment core retrieved nearshore off Cape Yubi (Plewa et al., 2006) showing that Ba is mainly associated with the clay fraction in this region. The results demonstrate that in the study area Ba - except for a few sites off Cape Ghir (c.f. Moreno et al., 2002) - is not a reliable tracer for surface water productivity.
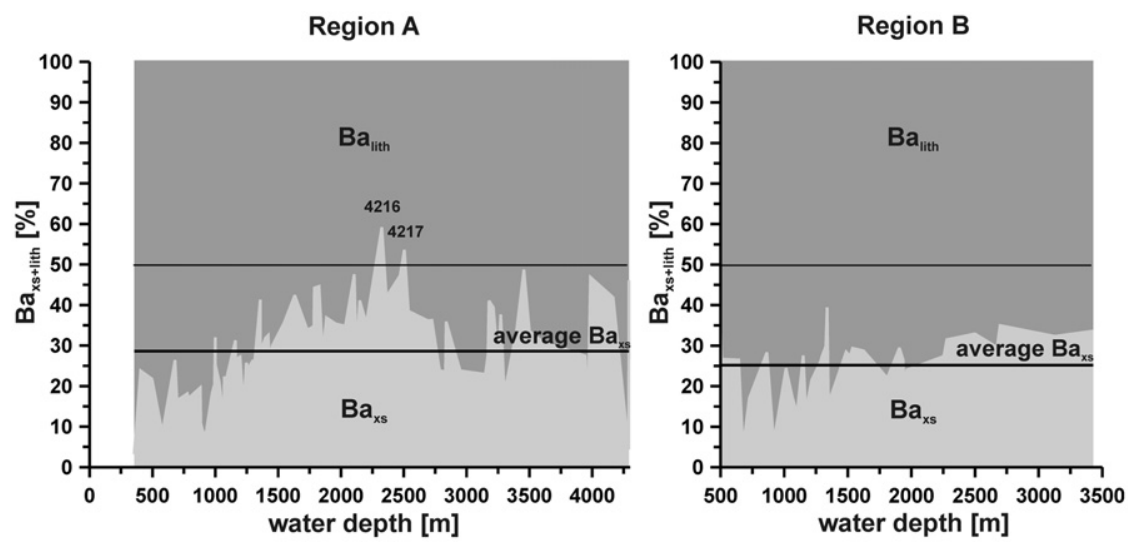

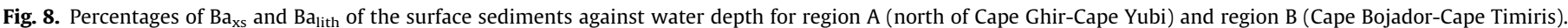

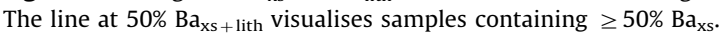




\subsection{Elements related to terrigenous input}

Lithogenic particles enter the marine environment either by fluvial or aeolian transport, with fluvial processes contributing by far the largest amounts of mineral detritus to the oceans (Milliman and Syvitski, 1992). Although the aeolian supply of terrigenous material towards the global ocean is about one order of magnitude less than the fluvial supply, its contribution to the sediment flux in the deep-sea is much higher, since river transported material is efficiently trapped on the continental shelves and slopes (Sarnthein et al., 1982).

Off the arid NW African continent the deposition of mineral dust is responsible for a large part of the deep-sea sedimentation (e.g., Chester and Johnson, 1971; Chester et al., 1972, 1979; Sarnthein and Koopmann, 1980; Sarnthein et al., 1982; Rea, 1994) and provides nutrients to the sea surface waters (e.g., Duce et al., 1991; Duce and Tindale, 1991; Gao et al., 2001; Baker et al., 2003; Gao et al., 2003; Jickells et al., 2005). Fluvial supply of terrigenous material is restricted to small areas in the north and the south of the study area and is mainly dependent on the hinterland climate. In the north, when snow melts on the Atlas and Anti-Atlas mountains and during rain-intensive seasons the river supply intensifies which has a significant influence on sedimentation. In general, the pattern of rainfall is caused by the mid-latitude westerlies (i.e., with the frontal systems within them) and the Intertropical Convergence Zone (ITCZ) (Nicholson, 2000). Therefore, rainfall-induced river supply is intensified north of the Sahara especially during boreal winter, the season of most intensive precipitation (Nicholson, 2000). South of $20^{\circ} \mathrm{N}$ summer rainfall occurs triggered by the humid SW monsoon flow and the upperlevel easterly flow over the continent (Nicholson, 2000).

Saharan dust consists mainly of a mixture of aluminosilicate phases - all containing variable amounts of silicon ( $\mathrm{Si})$, aluminium ( $\mathrm{Al}$ ), and also iron ( $\mathrm{Fe}$ ) and potassium (K) (Caquineau et al., 1998) - and is rich in titanium (Ti) (Schütz and Rahn, 1982). Therefore, the terrigenous source elements $\mathrm{Al}, \mathrm{K}, \mathrm{Ti}$ and $\mathrm{Fe}$ (respectively their element/aluminium ratios) were used in this study to trace the influence of the terrigenous input (aeolian and fluvial) and their possible source regions. Thereby it is assumed that sediments influenced by fluvial terrigenous input contain high amounts of clay (Diester-Haas, 1983).

In the form of rutile $\left(\mathrm{TiO}_{2}\right)$, sphene $\left.(\mathrm{CaTiSiO})_{5}\right)$ and ilmenite $\left(\mathrm{FeTiO}_{3}\right), \mathrm{Ti}$ is carried in the silt and fine-sand fractions during particle transportation, accompanying slightly coarser quartz grains. Only a small amount of Ti resides in the clay fraction where it substitutes for $\mathrm{Al}, \mathrm{Fe}, \mathrm{Mn}$ and perhaps $\mathrm{Si}$ in the lattices of a wide range of aluminosilicates. In general, the Ti/Al ratio can be used as a grain-size proxy because the heavy minerals are the main Ti carrier in many sediments (Calvert and Pedersen, 2007 and references therein). However, closer to sources like volcanic islands and seamount chains, Ti contents of the bulk sediments increase due to the derivation of augite, a well-known host for $\mathrm{Ti}$, from basaltic rocks. Trace quantities of ilmenite $\left(\mathrm{FeTiO}_{3}\right)$ would also be expected from this source. This shows that Ti has multiple sources and hosts in marine sediments (Calvert and Pedersen, 2007). Al contents in marine sediments generally can be assigned to the fine-grained aluminosilicate detrital fraction (Calvert, 1976). $\mathrm{K}$ is associated with potassium feldspar ( $\left.\mathrm{K}\left[\mathrm{AlSi}_{3} \mathrm{O}_{8}\right]\right)$ (Schneider et al., 1997; Martinez et al., 1999), although illite $\left(\left(\mathrm{K}, \mathrm{H}_{3} \mathrm{O}\right) \mathrm{Al}_{2}\left[(\mathrm{OH})_{2} \mathrm{Si}_{3} \mathrm{AlO}_{10}\right]\right)$ has also been considered to be the primary source of $\mathrm{K}$ (Yarincik et al., 2000). Fe can be contained in variable amounts in the aluminosilicate detrital fraction (Caquineau et al., 1998) as well as different iron oxides like goethite and hematite (Balsam et al., 1995). Regional differences in the geology of the source area and in the type and intensity of weathering are assumed to lead to variations in these affiliations.

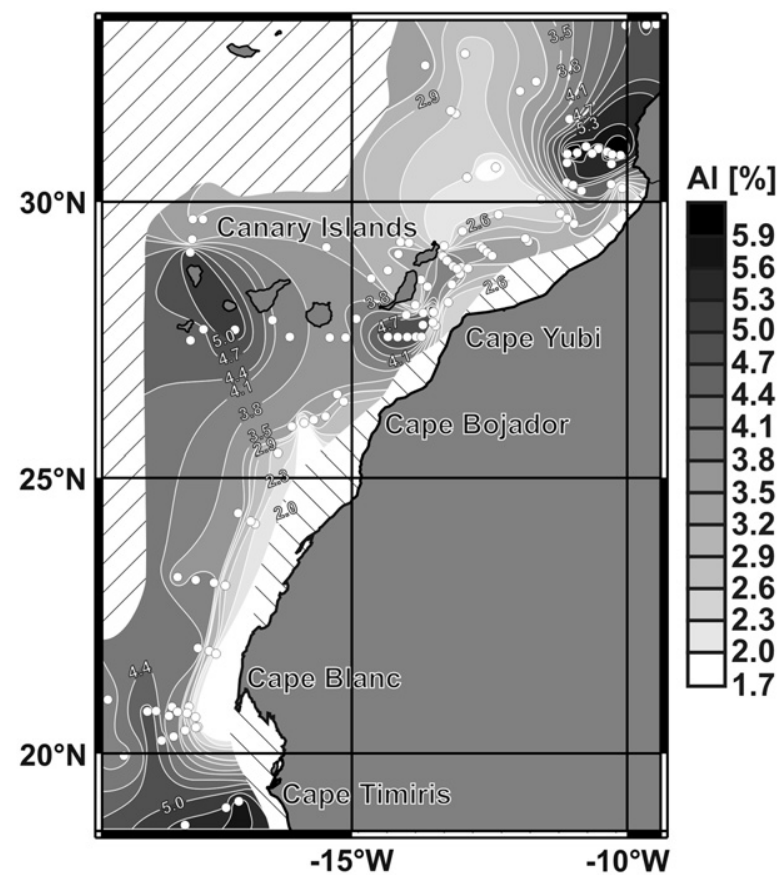

Fig. 9. Spatial distribution of aluminium (Al) concentration in $\%$ in the surface sediments from the Canary Islands region.

\subsubsection{Aluminium}

The distribution of the $\mathrm{Al}$ contents of the investigated surface sediments (Fig. 9) shows an opposite pattern compared to the spatial variability of $\mathrm{CaCO}_{3}$ (Fig. 5). Al contents are highest in the vicinity of Cape Timiris, Cape Ghir and Cape Yubi as well as offshore south of the Canary Islands. Lowest values are reached in the open ocean north of the Canary Islands. In the entire study area aluminium contents range from minimum values of $1.8 \%$ off Cape Bojador towards maximum values of $6.2 \%$ off Cape Ghir.

It is assumed that the Al contents in the investigated surface sediments mainly represent the fine-grained aluminosilicate detrital fraction (Calvert, 1976). But since the aluminium distribution pattern is influenced by varying amounts of dilution with other main components like carbonate as discussed before, the use of total sedimentary aluminium contents to trace different transport processes and related climatic regimes can lead to misinterpretations. Therefore, we will focus only on the $\mathrm{K} / \mathrm{Al}$, $\mathrm{Fe} / \mathrm{Al}$ and $\mathrm{Ti} / \mathrm{Al}$ ratios in the following discussion, since they will reveal subtle changes in the chemical composition of the sediments, which are not caused by dilution with $\mathrm{CaCO}_{3}$.

\subsubsection{Potassium}

The spatial distribution of the potassium/aluminium (K/Al) ratios (Fig. 10(A)) displays the highest values along the coast $(>0.44)$ and the lowest values offshore $(<0.24)$. It becomes evident that enhanced $\mathrm{K} / \mathrm{Al}$ ratios are extended far offshore in the northern part of the region off Cape Ghir.

Potassium and its main mineralogical carrier illite are frequently used to infer the supply of terrigenous material to marine sediments (e.g., Fütterer, 1983; Sirocko et al., 2000; Yarincik et al., 2000), for climatic (arid/humid) changes of the source region (Schneider et al., 1997; Kuhlmann et al., 2004) and for identification of source regions of aeolian dust (Delany et al., 1967; Caquineau et al., 1998; Goudie and Middleton, 2001; Caquineau et al., 2002; Stuut et al., 2005). In the investigated area near the coast of NW Africa river discharge has to be considered as a transport process of terrigenous material as described before. Since the illite content of marine sediments 

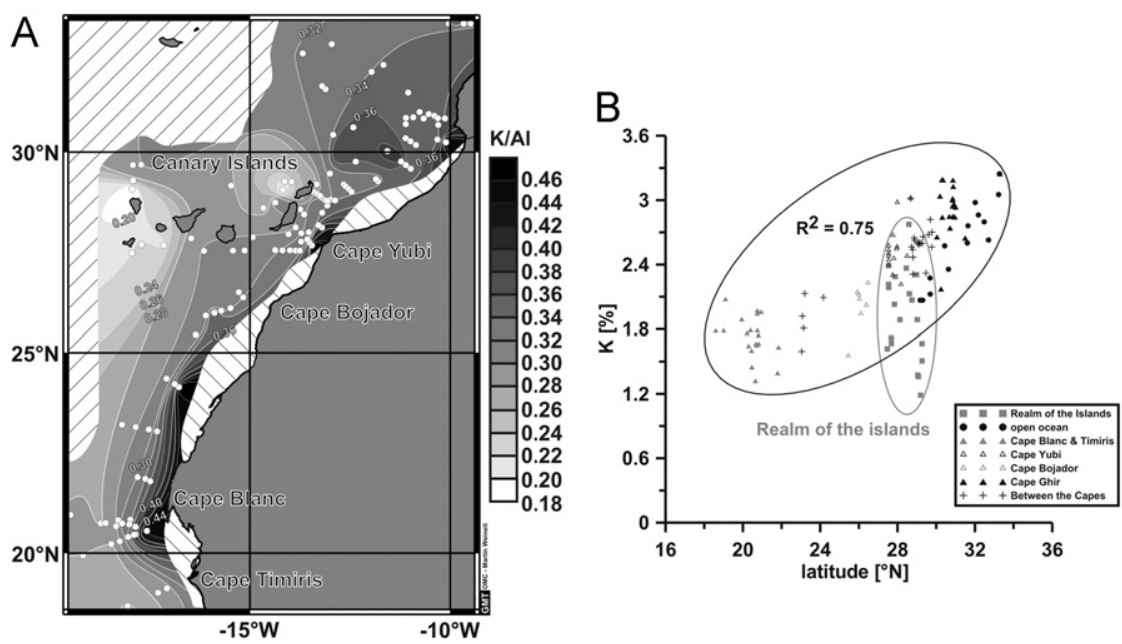

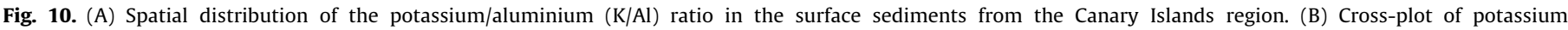

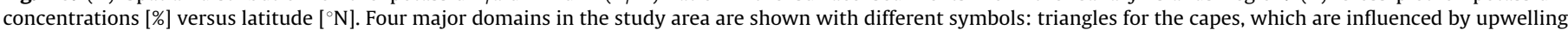

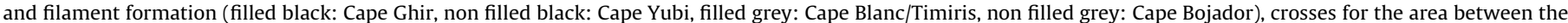

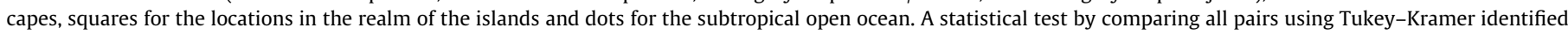

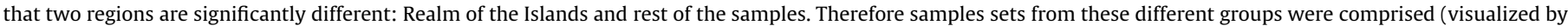
ellipses) and the correlation coefficient $\left(R^{2}\right)$ for the group "rest" is included.

impressively reflects the percentage and distribution of terrigenous particles being introduced into the sediments by fluvial transport (Fütterer, 2000), significantly increased K/Al ratios of the surface sediments suggest such a fluvial supply.

Highest K/Al ratios are found in shallower depths along the coast and additionally in the northern part of the region (north of $30^{\circ} \mathrm{N}$ ). It is suggested that two different transport mechanisms (aeolian and/or fluvial supply) can be responsible for the observed distribution pattern. Thereby the geology of the hinterland plays also an important role when interpreting the $\mathrm{K} / \mathrm{Al}$ results.

3.3.2.1. River supply. Since the spatial K/Al distribution shows slightly higher values north of $29^{\circ} \mathrm{N}$ (Fig. $10(\mathrm{~A})$ ), it is assumed that an enhanced fluvial discharge of terrigenous material plays an important role in this part of the region. This interpretation is supported by studies showing that sediment is discharged to the subtropical eastern North Atlantic by the Souss river (Ercilla et al., 1998; Wynn et al., 2000). Additionally, grain-size end-member analyses of surface samples from this region (Holz et al., 2004) are in good accordance with our results. These authors have shown that the fine-grained fraction representing river-sourced mud is confined to the area off Cape Ghir, where it constitutes up to $90 \%$ of the relative sediment composition. Hence, the signal of wind transported terrigenous material in seabed sediments in the northern part of the investigation area is overprinted by the signal of riverine terrigenous matter from southern Morocco and the drainage of the Atlas and Anti-Atlas Mountains. Additionally, the enhanced values found in the shallower sediments along the coast are supposed to be also a product of episodic riverine detritus, since it is known that river transported material is efficiently trapped on the continental shelves and slopes (Sarnthein et al., 1982).

3.3.2.2. Dust supply. South of $29^{\circ} \mathrm{N}$, climatic conditions are known to be more arid and, therefore, the terrigenous supply mainly occurs as aeolian dust. This is also valid for the offshore sediments, which are known to be mainly influenced by aeolian input of detrital material (Sarnthein et al., 1982). The observed low K/Al ratios in the surface sediments of the open ocean indicate the influence of the input of dust from deserts, which are known to be poor in illite (e.g., Petschick et al., 1996). Since the high ratios of $>0.36$
(Fig. 10(A)) in the shallow sediments nearshore are clearly higher than the $\mathrm{K} / \mathrm{Al}$ ratios of $0.23-0.30$ observed in dust samples from the region between $28^{\circ} \mathrm{N}$ and $19^{\circ} \mathrm{N}$, it is assumed that in addition to aeolian input the fluvial supply of terrigenous matter is also of importance for the K/Al distribution pattern here.

3.3.2.3. Hinterland geology. The spatial variability of the K/Al ratios of the surface sediments can also be related to the differences in hinterland geology of the North African continent as well as of the Canary Islands. The $\mathrm{K} / \mathrm{Al}$ ratios and the total $\mathrm{K}$ contents slightly increase with increasing latitude (Fig. 10(A) and (B), except for the area in the realm of the islands), especially south of $20^{\circ} \mathrm{N}$, lower ratios were identified in shallower sediments. The North and Central Sahara are characterised by high illite contents, whereas soils of the South Sahara and Sahel (south of $20^{\circ} \mathrm{N}-25^{\circ} \mathrm{N}$ ) contain less illite but abundant amounts of kaolinite as shown by dust and soil mineralogical studies (e.g., Chester et al., 1972; Sarnthein et al., 1982; Avila et al., 1996; Chiapello et al., 1997; Caquineau et al., 1998, 2002). Windom (1975) and Johnson (1979) have shown mineralogical similarities between the composition of African dust and sediments of the North Atlantic. The spatial distribution patterns of $\mathrm{K} / \mathrm{Al}$ and $\mathrm{K}$ are consistent with these sediment, dust and soil mineralogical studies and can therefore be linked to aerosol and soil composition changes over North Africa.

The K/Al ratio of the sediments in the vicinity of the Canary Islands with the overall lowest values of $0.2-0.24$ are in good agreement with the $\mathrm{K} / \mathrm{Al}$ ratio of 0.2 determined for young basanite samples from Gran Canaria (Hoernle and Schmincke, 1993). Therefore, it is concluded that the distribution pattern of the sedimentary $\mathrm{K} / \mathrm{Al}$ ratio in the realm of the volcanic islands is influenced by their soil composition, regardless of the transport process. We conclude therefore that the K/Al ratio in the study area is a suitable tracer for the fluvial supply of terrigenous material as well as for the identification of different source areas.

\subsubsection{Iron and titanium}

Iron and titanium contents in marine sediments and dust samples are frequently used for identification of terrigenous supply to marine sediments (Schütz and Rahn, 1982; Fütterer, 1983; Jickells, 1995; Sirocko et al., 2000; Yarincik et al., 2000; 
Bozzano et al., 2002; Guieu et al., 2002), for climatic reconstructions (Zabel et al., 1999; Yarincik et al., 2000; Zabel et al., 2001; Kuhlmann, 2004) and for identification of source regions of aeolian dust (Coude-Gaussen et al., 1987; Bergametti et al., 1989; Balsam et al., 1995; Chiapello et al., 1997; Stuut et al., 2005).

In the study area the iron/aluminium ratios $(\mathrm{Fe} / \mathrm{Al}$ ) range between 0.4 and 1.5 (Fig. 11(A)). They reach maximum values in the vicinity of the islands and minimum values in sediments from water depths greater than $1000 \mathrm{~m}$. The distribution pattern of the Fe/Al ratio of the surface sediments shows a slightly zonal gradient along the NW African coast with higher values nearshore and lower values in the open ocean and again an increase of the ratio towards the Canary Islands (Fig. 11(A)). Similar to the K/Al distribution pattern the $\mathrm{Fe} / \mathrm{Al}$ ratios reveal higher values along the coast.

Similar to the distribution pattern of the $\mathrm{Fe} / \mathrm{Al}$ ratios, $\mathrm{Ti} / \mathrm{Al}$ ratios reach maximum values in the realm of the Canary archipelago (Fig. 11(B)). Additionally, the Ti/Al ratio of the surface sediment reveals a zonal gradient with clearly lower values along the African coast and higher values offshore. In the study area $\mathrm{Ti} / \mathrm{Al}$ ratios range from the lowest values of 0.054 off Cape Ghir towards the highest values of 0.25 north of the island of La Palma. A diagenetic overprint of iron can be excluded since in the entire study area oxic conditions exist in the bottom water as well as in the upper few centimetres of the sediment as shown by various investigations (e.g., Neuer et al., 2000; Meggers et al., 2003; Meinecke et al., 2003; Bleil et al., 2004; Meinecke et al., 2005; Ruhland et al., 2005). Regarding the spatial distribution of the $\mathrm{Fe} / \mathrm{Al}$ and $\mathrm{Ti} / \mathrm{Al}$ ratios (Fig. 11(A) and (B)) samples in the realm of the islands can be distinguished from the rest of the samples. A statistical test comparing all pairs of the four major domains (defined after Meggers et al., 2002) using Tukey-Kramer, demonstrated that the samples from the realm of the islands are significantly different to all other samples. For both groups a good correlation between the total contents of $\mathrm{Fe}$, Ti and $\mathrm{Al}$ is observed (Fig. 12(A)-(C)). Therefore we conclude that this points to similar origins and transport pathways of the $\mathrm{Fe}, \mathrm{Ti}$ and $\mathrm{Al}$ containing terrigenous material.

The Fe and Ti contents as well as the related $\mathrm{Fe} / \mathrm{Al}$ and $\mathrm{Ti} / \mathrm{Al}$ ratios of the samples in the realm of the islands (referred to as samples $_{\text {islands }}$ in the following) are clearly higher than the contents and ratios of the rest of the surface samples (samples rest $_{\text {) }}$ (Fig. 11(A) and (B), Fig. 12(A)-(C)). We assume that the observed distribution pattern can be related to the difference between the mineral assemblage coming from the volcanic basalts and gabbros of the islands (Kuss and Kremling, 1999) and from the potential Saharan sources (mainly clay minerals, calcite and quartz). This assumption is supported by the slight accordance between the determined $\mathrm{Ti} / \mathrm{Al}$ ratios ranging from 0.1 to 0.25 in

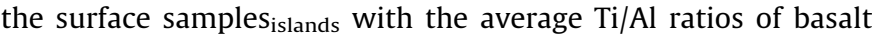
and basaltic rocks of 0.1 and 0.18 (Table 1, Turekian and Wedepohl, 1961; Vinogradov, 1962).

Minimum and average Ti/Al values of 0.05-0.09 are in good accordance with $\mathrm{Ti} / \mathrm{Al}$ ratios of the upper continental crust and river suspended matter (Table 1 ) as well as with the Ti/Al ratio of Northern Saharan dust (0.09, Ganor et al., 1991). Therefore sur-

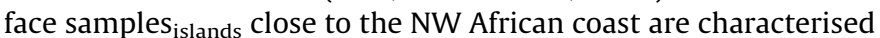
by lower ratios whereas the Ti/Al ratios of surface samples rest increase with increasing distance from the coast. This leads to the hypothesis that the dominance of Saharan dust as a main source for lithogenic material from the African continent increases with greater distance from the coast. Additionally, lateral advection has to be taken into account to be responsible for the observed distribution pattern. It is possible that bottom currents lead to an enhanced transport of the heavier grains to the deeper ocean.

The determined $\mathrm{Fe} / \mathrm{Al}$ ratios of the surface samples islands\&rest can (like $\mathrm{K} / \mathrm{Al}$ and $\mathrm{Ti} / \mathrm{Al}$ ) be related to the different sources Canary Islands and African continent. A comparison between the $\mathrm{Fe} / \mathrm{Al}$ ratios of the surface sediment samples and the $\mathrm{Fe} / \mathrm{Al}$ ratios of dust samples (Table 1, Bergametti et al., 1989) reveals that they are unsuitable to identify different continental source regions (like e.g., Morocco or Sahel zone). However, the attribution of the $\mathrm{Fe} / \mathrm{Al}$ ratios of the surface samples to the Canary Islands as an important source region for volcanic material is also evident as for the Ti/Al ratios. Probably the distribution of Fe/ $\mathrm{Al}$ ratios in the surface sediments is more affected by the hinterland climate than the surface sediment $\mathrm{Ti} / \mathrm{Al}$ ratios. This hypothesis is supported by the observed distribution pattern of surface samples Fe/Al ratios (Fig. 11(A)) at nearshore locations, which is comparable with that of the $\mathrm{K} / \mathrm{Al}$ ratios (Fig. 10(A)).

It is important to note that the distribution of the $\mathrm{Ti} / \mathrm{Al}$ ratios and $\mathrm{Fe} / \mathrm{Al}$ ratios reveals the different source regions like the
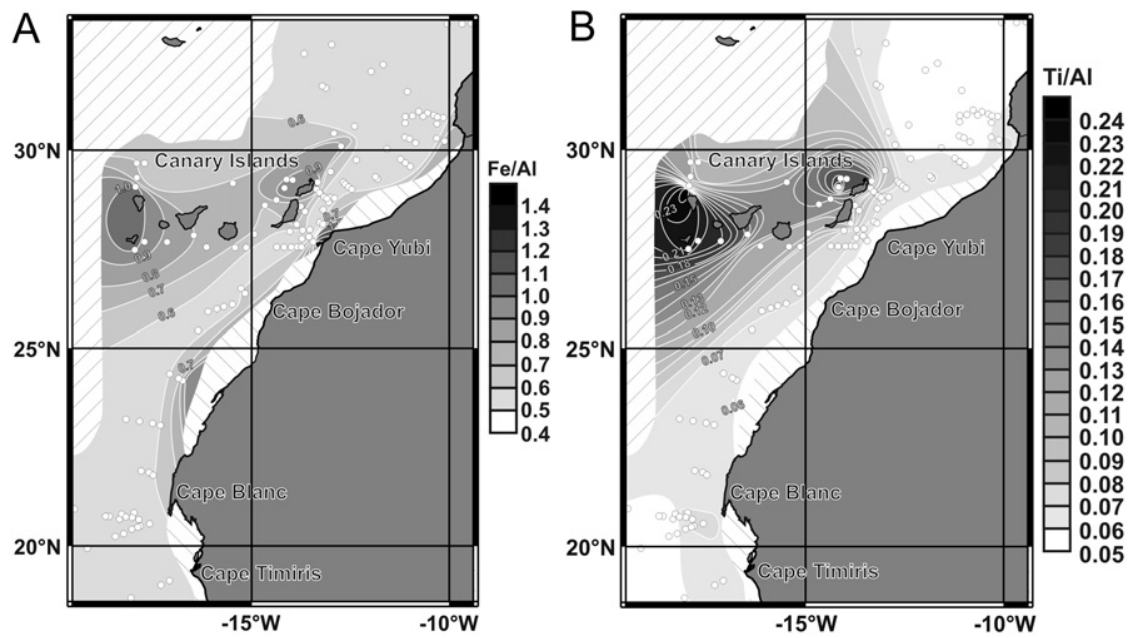

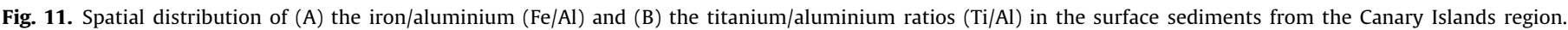

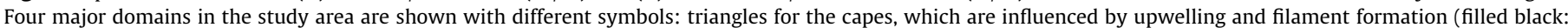

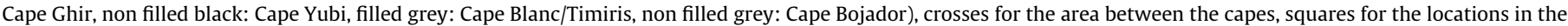

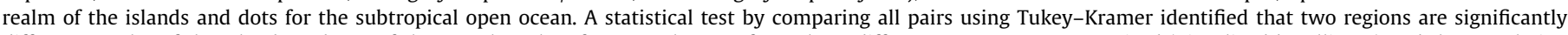

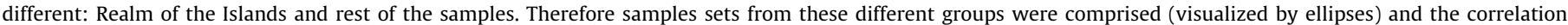
coefficient $\left(R^{2}\right)$ for the group "rest" is included. 

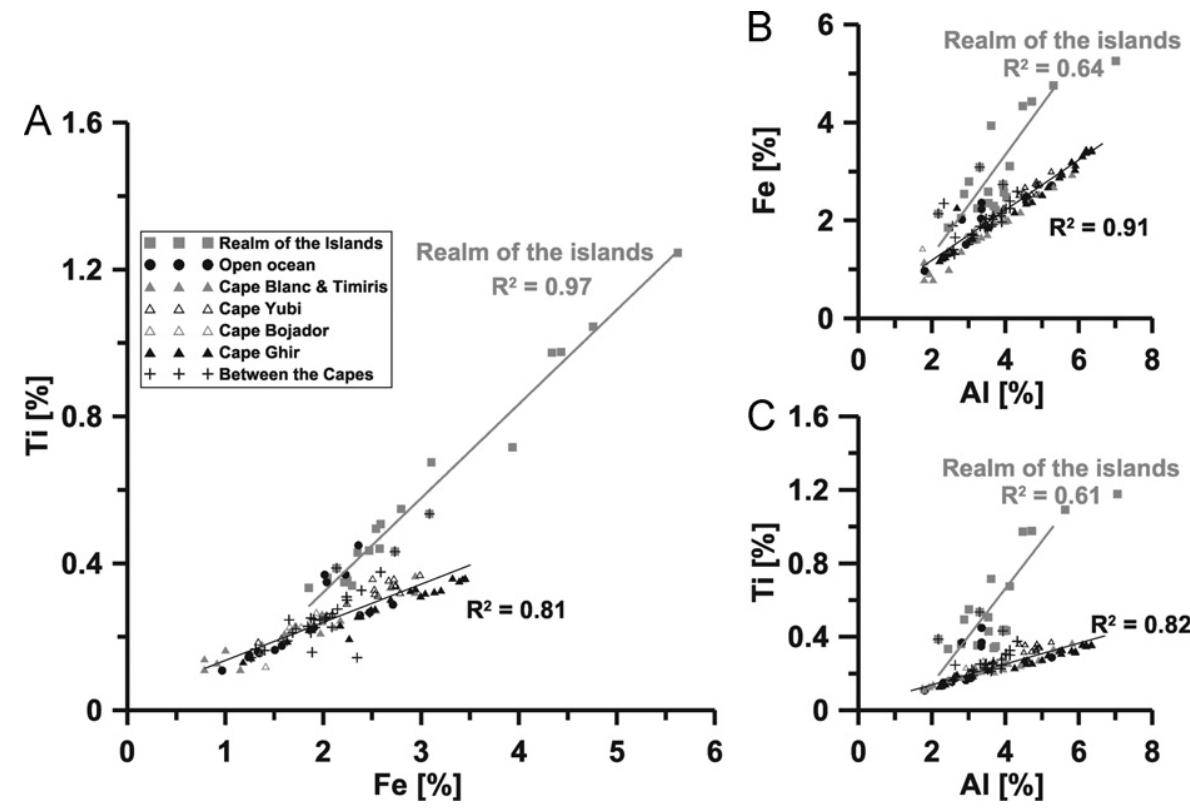

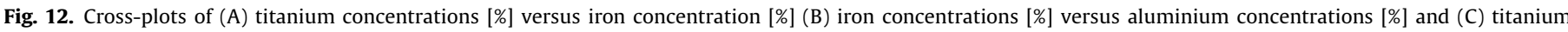

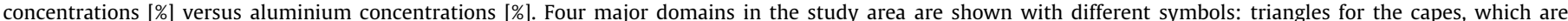

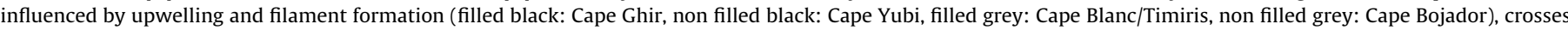

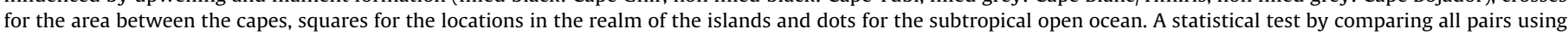

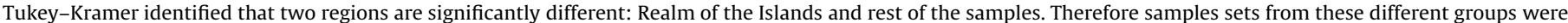
comprised and the related significant correlation coefficients $\left(R^{2}\right)$ are included.

volcanic Canary Islands and the NW African continent. Furthermore, the distribution pattern of both ratios of the surface samples $_{\text {rest }}$ is partly comparable with that of the K/Al ratios (Fig.10(A)), representing the different transport mechanisms, differences in the hinterland climates and also changes in geology and soil composition of the different source areas of NW Africa.

\section{Conclusions}

The geochemical data of surface sediments from the Canary Islands region clearly reflects the great heterogeneity of this region. Sedimentation in the study area is affected by a complex interaction of aeolian and fluvial input from different source regions as well as ocean water productivity and ocean currents. Despite these various influencing factors the multi-tracer approach of this study proves useful for tracing present day oceanographic and climatic conditions as well as different source areas of terrigenous material.

The surface sediment TOC distribution reflects the surface water productivity off NW Africa with highest contents nearshore - especially in the vicinity of the capes - and lowest contents offshore. This fact and the finding that organic matter of terrestrial origin is not delivered to the seafloor in significant amounts leads to the assumption that TOC is a reliable tracer for (paleo)productivity reconstructions in the investigated region. In contrast, calcium carbonate contents and $\mathrm{Ba} / \mathrm{Al}$ ratios of the surface sediments do not mirror ocean surface water productivity in the region of the Canary Islands. The carbonate content is mainly controlled by dilution with terrigenous matter. The Ba content of the surface sediments mainly reflects the input of Ba adsorbed onto and/or incorporated into aluminosilicates.

Surface sediment K/Al distributions in the NW African region are reliable tracers for variations in geology and climatic conditions of the hinterland as well as for related transport mechanisms. The distribution pattern reveals the existence of a humid influenced region north of $29^{\circ} \mathrm{N}$. There the rivers supply most of the terrigenous material. South of $29^{\circ} \mathrm{N}$ arid conditions prevail and, hence, the terrigenous input mainly occurs via aeolian dust, except for the nearshore area along the NW African coast where also a fluvial influence is evident. Besides its relevance as a tracer for humid conditions, the surface sediment $\mathrm{K} / \mathrm{Al}$ distribution is a very suitable parameter to identify the different source regions of terrigenous material. It reflects the mineralogical composition of soils of the hinterland which are characterised by high illite contents in the North and the Central Sahara and by high kaolinite but minor illite contents in the South Sahara and Sahel (south of $20^{\circ} \mathrm{N}-25^{\circ} \mathrm{N}$ ). Additionally, the geology of the volcanic Canary Islands which is characterized by low $\mathrm{K} / \mathrm{Al}$ ratios is well mirrored in the surrounding sediments.

Another important result of this study is that the Ti/Al ratio of the surface sediments is well suited for identification of the influence of the Canary Islands as an important source region for the input of terrigenous - volcanic - material to the seafloor. Comparably, $\mathrm{Fe} / \mathrm{Al}$ ratios are also useful to trace the input of volcanic material from the islands. However, the distribution pattern of the surface sediment $\mathrm{Fe} / \mathrm{Al}$ is also influenced by the fluvial supply of terrigenous material to nearshore sediments.

This study shows that the distribution patterns of the investigated geochemical tracers allows the identification of different regions which clearly differ with respect to sedimentary composition. On the one hand we defined the "nearshore regions", whose sediment composition is mainly influenced by surface ocean productivity, the different climatic conditions of the NW African continent resulting in different transport pathways (dominance of a fluvial input in more humid regions and of an aeolian input in more arid regions) and the mineralogical composition of the hinterland. The second region is the "offshore region", being mainly characterised by low surface ocean water productivity and dust delivered lithogenic material. Furthermore, a third region could be clearly identified which is mainly influenced by the terrigenous - volcanic - input from the Canary Islands.

Further investigations of the mineralogical composition of the surface sediments and additional soil samples are necessary to 
trace the possible source regions of the terrigenous fraction. A direct comparison with dust samples from this region also could lead to a better understanding of the transport pathways of aeolian material.

\section{Acknowledgments}

We thank the masters, crews and scientific participants of RVs Meteor, Poseidon and Victor Hensen for their strong support during the eight cruises. For technical laboratory assistance, we are indebted to S. Pape, S. Siemer and K. Enneking. We highly appreciate the support by $\mathrm{M}$. Segl and for running the CHNAnalyser. Furthermore, we thank K. Wien for very helpful comments. We would also like to thank Andreas Lückge, Christian März and two anonymous reviewers whose constructive comments were most valuable to improve the manuscript. This research was funded by the Deutsche Forschungsgemeinschaft (DFG)as part of the International Graduate College "Proxies in Earth History" (EUROPROX) of the University of Bremen. Additional support was provided by the Helmholtz Association (AWI Bremerhaven).

\section{Appendix A. Supporting information}

Supplementary data associated with this article can be found in the online version at doi:10.1016/j.dsr.2012.04.005.

\section{References}

Arimoto, R., Duce, R.A., Ray, B.J., Ellis Jr., W.G., Cullen, J.D., Merrill, J.T., 1995. Trace elements in the atmosphere over the North Atlantic. J. Geophys. Res. 100, 1199-1213.

Adelseck, C.G., Berger, W.H., 1975. On the dissolution of planktonic foraminifera and associated microfossils during settling and on the sea floor. Cushman Foundation for Foraminiferal Research Special Publication No. 13, pp. 70-81.

Avila, A., Queralt, I., Gallart, F., Martin-Vide, J., 1996. African dust over northeastern Spain: mineralogy and source regions. In: Chester, R. (Ed.), The Impact of Desert Dust Across the Mediterranean. Kluwer Academic Publishing, Dordrecht, pp. 201-205.

Baker, A.R., Kelly, S.D., Biswas, K.F., Witt, M., Jickells, T.D., 2003. Atmospheric deposition of nutrients to the Atlantic Ocean. Geophys. Res. Lett. 30, 24.

Balsam, W.L., Otto-Bliesner, B.L., Deaton, B.C., 1995. Modern and last glacia maximum eolian sedimentation patterns in the Atlantic ocean interpreted from sediment iron oxide content. Paleoceanography 10, 493-507.

Barton, E.D., Arístegui, J., 2004. The Canary Islands coastal transition zone upwelling, eddies and filaments. Prog. Oceanogr. 62, 67-69.

Barton, E.D., Aristegui, J., Tett, P., Canton, M., Garcia-Braun, J., Hernandez-Leon, S. Nykjaer, L., Almeida, C., Almunia, J., Ballesteros, S., 1998. The transition zone of the Canary Current upwelling region. Prog. Oceanogr. 41, 455-504.

Bergametti, G., Gomes, L., Coudé-Gaussen, G., Rognon, P., Le Coustumer, M.N. 1989. African dust observed over Canary Islands: source-regions identification and transport pattern for some summer situations. J. Geophys. Res. 94, 14855-14864.

Berger, W.H., 1967. Foraminiferal ooze: solution at depths. Science 156, 383-385

Berger, W.H., 1968. Planktonic foraminifera: selective solution and paleoclimatic interpretation. Deep Sea Res. 15, 31-43.

Berger, W.H., Bonneau, M.-C., Parker, F.L., 1982. Foraminifera on the deep-sea floor: lysocline and dissolution rate. Oceanolog. Acta 5, 249-258.

Bishop, J.K.B., 1988. The barite-opal-organic carbon association in oceanic particulate matter. Nature 332, 341-343.

Bleil, U., Bickert, T., Brück, L., Dehning, K., Dimmler, W., Epplé, V., Fischer, G., Franke, P., Frederichs, T., Freudenthal, T., Gerrits, A., Hessler, C.S., Hilgenfeldt, C., Joppich, C. Kasten, S., Klann, M., Köbrich, M., Kölling, M., Meggers, H., Müller, H., Nowald, N., Paulsen, H., Plewa, K., Ratmeyer, V., Riedinger, N., Schmieder, F., Schmidt, M. Schnieders, L., Susek, E., Szuba, K., Tjallingii, R., Truscheit, T., Wien, K., Wilke, I., Wilhelm, O., Wülbers, A., Zatloukal, N., 2004. Report and preliminary results of METEOR Cruise M58/2, Las Palmas - Las Palmas (Canary Islands, Spain), 15.05.2003-08.06.2003. Berichte Fachbereich Geowissenschaften 227, 123. Universität Bremen, Bremen.

Bordovskiy, O.K., 1965a. Accumulation of organic matter in bottom sediments. Mar. Geol. 3, 33-82.

Bordovskiy, O.K., 1965b. Sources of organic matter in marine basins. Mar. Geol. 3, 5-31.

Bozzano, G., Kuhlmann, H., Alonso, B., 2002. Storminess control over African dus input to the Moroccan Atlantic margin (NW Africa) at the time of maxima boreal summer insolation: a record of the last 220 kyr. Palaeogeogr. Palaeoclimatol. Palaeoecol. 183, 155-168.

Broecker, W.S., Takahashi, T., 1978. The relationship between lysocline depth and in situ carbonate ion concentration. Deep Sea Res. 25, 65-95.

Calvert, S.E., 1976. The mineralogy and geochemistry of nearshore sediments In: Chester, R. (Ed.), Treatise on Chemical Oceanography. Academic Press, San Diego, pp. 187-280.

Calvert, S.E., Pedersen, T.F., 2007. Chapter fourteen elemental proxies for palaeoclimatic and palaeoceanographic variability in marine sediments: interpretation and application. In: Hillaire-Marcel, C., De Vernal, A. (Eds.), Developments in Marine Geology, Vol. 1. Elsevier, pp. 567-644.

Caquineau, S., Gaudichet, A., Gomes, L., Legrand, M., 2002. Mineralogy of Saharan dust transported over northwestern tropical Atlantic Ocean in relation to source regions. J. Geophys. Res. 107, 4251, http://dx.doi.org/10.1029/2000JD000247.

Caquineau, S., Gaudichet, A., Gomes, L., Magonthier, M.-C., Chatenet, B., 1998 Saharan dust: clay ratio as a relevant tracer to assess the origin of soil-derived aerosols. Geophys. Res. Lett. 25, 983-986.

Chester, R., Elderfield, H., Griffin, J.J., Johnson, L.R., Padgham, R.C., 1972. Eolian dust along the eastern margins of the Atlantic Ocean. Mar. Geol. 13, 91-105.

Chester, R., Griffiths, A.G., Hirst, J.M., 1979. The influence of soil-sized atmospheric particulates on the elemental chemistry of the deep-sea sediments of the northeastern Atlantic. Mar. Geol. 32, 141-154.

Chester, R., Johnson, L.R., 1971. Atmospheric dusts collected off the West African coast. Nature 229, 105-107.

Chiapello, I., Bergametti, G., Chatenet, B., Bousquet, P., Dulac, F., Santos Soares, E. 1997. Origins of African dust transported over the northeastern tropical Atlantic. J. Geophys. Res. 102, 13,701-713,709.

Coude-Gaussen, G., Rognon, P., Bergametti, G., Gomes, L., Strauss, B., Gros, J.M. Le Coustumer, M.N., 1987. Saharan dust on Fuerteventura Island (Canaries): chemicalm and mineralogical characteristics, air mass trajectories, and probable sources. J. Geophys. Res. 92, 9753-9771.

Davenport, R., Neuer, S., Helmke, P., Perez-Marrero, J., Llinas, O., 2002. Primary productivity in the northern Canary Islands region as inferred from SeaWiFS imagery. Deep Sea Res. Part II: Top. Studies Oceanogr. 49, 3481-3496.

Davenport, R., Neuer, S., Hernandez-Guerra, A., Rueda, M.J., Llinas, O., Fischer, G. Wefer, G., 1999. Seasonal and interannual pigment concentration in the Canary Islands region from CZCS data and comparison with observations from the ESTOC. Int. J. Remote Sens. 20, 1419-1433.

de Villiers, S., 2005. Foraminiferal shell-weight evidence for sedimentary calcite dissolution above the lysocline. Deep Sea Res. Part I: Oceanogr. Res. Papers 52, 671-680.

Dehairs, F., Chesselet, R., Jedwab, J., 1980. Discrete suspended particles of barite and the barium cycle in the open ocean. Earth Planet. Sci. Lett. 49, 528-550.

Dehairs, F., Fagel, N., Antia, A.N., Peinert, R., Elskens, M., Goeyens, L., 2000. Export production in the Bay of Biscay as estimated from barium - barite in settling material: a comparison with new production. Deep Sea Res. Part I: Oceanogr. Res. Papers 47, 583-601.

Delany, A.C., Parkin, D.W., Griffin, J.J., Goldberg, E.D., Reimann, B.E.F., 1967. Airborne dust collected at Barbados. Geochim. Cosmochim. Acta 31, 885-909.

Diester-Haas, L., 1976. Late Quaternary climatic variations in northwest Africa deduced from east Atlantic sediment cores. Quat. Res. 6, 299-314.

Diester-Haas, L., 1983. Differentiation of high oceanic fertility in marine sediments caused by coastal upwelling and/or river discharge off Northwest Africa. In: Suess, E. (Ed.), Coastal Upwelling: Its Sediment Record, Part B. Sediment Records of Ancient Coastal Upwelling. Plenum Press, New York and London, pp. 399-419.

Duce, R.A., Liss, P.S., Merrill, J.T., Atlas, E.L., Buat-Menard, P., Hicks, B.B., Miller, J.M., Prospero, J., Arimoto, R., Church, T.M., Ellis, W., Galloway, J.N., Hansen, L., Jickells, T.D., Knap, A.H., Reinhardt, K.H., Schneider, B., Soudine, A., Tokos, J.J., Tsunogai, S., Wollast, R., Zhou, M., 1991. The atmospheric input of trace species to the world ocean. Global Biogeochem. Cycles 5, 193-259.

Duce, R.A., Tindale, N.W., 1991. Atmospheric transport of iron and its deposition in the ocean. Limnol. Oceanogr. 36, 1715-1726.

Dymond, J., Suess, E., Lyle, M., 1992. Barium in deep-sea sediments: a geochemical proxy for paleoproductivity. Paleoceanography 7, 163-181.

Eberwein, A., Mackensen, A., 2006. Regional primary productivity differences off Morocco (NW-Africa) recorded by modern benthic foraminifera and their stable carbon isotopic composition. Deep-Sea Res. I 53, 1379-1405.

Eglinton, T.I., Eglinton, G., Dupont, L., Sholkovitz, E.R., Montlucon, D., Reddy, C.M., 2002. Composition, age, and provenance of organic matter in NW African dust over the Atlantic Ocean. Geochem. Geophys. Geosyst. 3, 8.

Emery, K.O., Uchupi, E., 1984. The Geology of the Atlantic Ocean. Springer, Berlin Heidelberg New York 1050 pp.

Ercilla, G., Alonso, B., Perez-Belzuz, F., Estrada, F., Baraza, J., Farran, M., Canals, M. Masson, D., 1998. Origin, sedimentary processes and depositional evolution of the Agadir turbidite system, central eastern Atlantic. J. Geol. Soc. 155, 929-939.

Faganelli, J., Malej, A., Pezdic, J., Malacic, V., 1988. C:N:P ratios and stable C isotopic ratios as indicator of sources of organic matter in the Gulf of Trieste (northern Adriatic). Oceanolog. Acta 11, 377-382.

Fagel, N., Andre, L., and Dehairs, F., 1999. Advective excess Ba transport as shown from sediment and trap geochemical signatures. Geochim. Cosmochim. Acta 63, 2353-2367ISI:000082767700003.

Feldman, G.C., C.R. McClain, 2012. Aqua MODIS Annual composite Chlorophyll concentration, Ocean Color Web. In: Kuring, N., Bailey, S.W., Franz, B.F., 
Meister, G., Werdell, P.J., Eplee, R.E. (Eds.), 02.03.2012. NASA Goddard Space Flight Center. 〈http://oceancolor.gsfc.nasa.gov/cgi/13〉.

Fischer, G., Behr, H.D., Berkenheger, I., Budziak, D., Dierssen, H., Dittert, N., von Dobeneck, T., Fabian, K., Gerhardt, S., Hespenheide, B., Höppner, R., Karwath, B., Lambers, K., v. Lom-Keil, H., Ochsenhirt, W.-T., Panteleit, B., Pierro, H., Ratmeyer, V., Romero, O., Rosiak, U., Rühlemann, K., Ruhland, G., Scholz, M., Sydow, U., Vidal, L., Wolff, T., Zatloukal, N., 1998. Report and preliminary results of METEOR Cruise M 38/1, Las Palmas - Recife, 25.01.1997-01.03.1997. Berichte Fachbereich Geowissenschaften 94, 178. Universität Bremen, Bremen.

Formenti, P., Elbert, W., Maenhaut, W., Haywood, J., Andreae, M.O., 2003. Chemical composition of mineral dust aerosol during the Saharan dust experiment (SHADE) airborne campaign in the Cape Verde region, September 2000. J. Geophys. Res. 108, 8576, http://dx.doi.org/10.1029/2002JD002648.

Francois, R., Honjo, S., Manganini, S.J., Ravizza, G.E., 1995. Biogenic barium fluxes to the deep sea: implications for paleoproductivity reconstruction. Global Biogeochem. Cycles 9, 289-303.

Freudenthal, T., Meggers, H., Henderiks, J., Kuhlmann, H., Moreno, A., Wefer, G., 2002. Upwelling intensity and filament activity off Morocco during the last 250,000 years. Deep Sea Res. Part II: Top. Studies Oceanogr. 49, 3655-3674.

Fütterer, D.K., 1983. The modern upwelling record of Northwest Africa. In: Suess, E. (Ed.), Coastal Upwelling: Its Sediment Record, Part B. Sediment Records of Ancient Coastal Upwelling. Plenum Press, London, pp. 105-121.

Fütterer, D.K., 2000. The solid phase of marine sediments. In: Zabel, M. (Ed.), Marine Geochemistry. Springer, Berlin Heidelberg, pp. 1-22.

Gabric, A.J., Garcia, L., Van Camp, L., Nykjaer, L., Eifler, W., Schrimpf, W., 1993. Offshore export of shelf production in the Cape Blanc (Mauritania) giant filament as derived from coastal zone color scanner imagery. J. Geophys. Res. 98, 4697-4712.

Ganeshram, R.S., Pedersen, T.F., 1998. Glacial-interglacial variability in upwelling and bioproductivity off NW Mexico: implications for Quaternary paleoclimate. Paleoceanography 13, 634-645.

Ganeshram, R.S., Pedersen, T.F., Calvert, S.E., Murray, J.W., 1995. Large changes in oceanic nutrient inventories from glacial to interglacial periods. Nature 376, 755-758.

Ganor, E., Foner, H.A., Brenner, S., Neeman, E., Lavi, N., 1991. The chemical composition of aerosols settling in Israel following dust storms. Atmos. Environ. Part A 25, 2665-2670.

Gao, Y., Fan, S.-M., Sarmiento, J.L., 2003. Aeolian iron input to the ocean through precipitation scavenging: a modeling perspective and its implication for natural iron fertilization in the ocean. J. Geophys. Res. 108 (D7).

Gao, Y., Kaufman, Y.J., Tanré, D., Kolber, D., Falkowski, P.G., 2001. Seasonal distributions of Aeolian Iron Fluxes to the global ocean. Geophys. Res. Lett. 28 (1), 29-32.

García-Muñoz, M., Aristegui, J., Montero, M.F., Barton, E.D., 2004. Distribution and transport of organic matter along a filament-eddy system in the Canaries NW Africa coastal transition zone region. Prog. Oceanogr. 62, 115-129.

Gingele, F., Dahmke, A., 1994. Discrete barite particles and barium as tracers of paleoproductivity in South Atlantic sediments. Paleoceanography 9, 151-168.

Gingele, F.X., Zabel, M., Kasten, S., Bonn, W.J., Nürnberg, C.C., 1999. Biogenic barium as a proxy for paleoproductivity: methods and limitations of application. In: Wefer, G. (Ed.), Use of Proxies in Paleoceanography: Examples from the South Atlantic. Springer-Verlag, Berlin Heidelberg, pp. 345-364.

Gladney, E.S., Roelandts, I., 1987. Compilation of elemental concentration data for USGS BHVO-1, MAG-1, QLO-1, RGM-1, SCo-1, SDC-1, SGR-1, and STM-1. Geostand. Newsletter 12, 253-362.

Goldberg, E.D., Arrhenius, G.O.S., 1958. Chemistry of pelagic Pacific sediments. Geochim. Cosmochim. Acta 13, 153-198.

Goudie, A.S., Middleton, N.J., 2001. Saharan dust storms: nature and consequences. Earth Sci. Rev, 56, 179-204.

Guieu, C., Loye-Pilot, M.-D., Ridame, C., Thomas, C., 2002. Chemical characterization of the Saharan dust end-member: Some biogeochemical implications for the western Mediterranean Sea. J. Geophys. Res. 107 (D15).

Hays, J.D., Peruzza, A., 1972. The significance of calcium carbonate oscillations in eastern equatorial Atlantic deep-sea sediments for the end of the Holocene warm interval. Quat. Res. 2, 355-362.

Henderiks, J., Freudenthal, T., Meggers, H., Nave, S., Abrantes, F., Bollmann, J., Thierstein, H.R., 2002. Glacial-interglacial variability of particle accumulation in the Canary Basin: a time-slice approach. Deep Sea Res. Part II: Top. Studies Oceanogr. 49, 3675-3705.

Hillier, S., 1995. Erosion, sedimentation and sedimentary and sedimentary origin of clays. In: Velde, B. (Ed.), Origin and Mineralogy of Clays-Clays and the Environment. Springer Verlag, Berlin, pp. 162-219.

Hoernle, K., Schmincke, H.-U., 1993. The petrology of the Tholeiites through Melilite Nephelinites on Gran Canaria, Canary Islands: crystal fractionation, accumulation, and depths of melting. J. Petrol. 34, 573-597, http://dx.doi.org/ 10.1093/petrology/34.3.573.

Holz, C., Stuut, J.-b.W., Henrich, R., 2004. Terrigenous sedimentation processes along the continental margin off NW Africa: implications from grain-size analysis of seabed sediments. Sedimentology 51, 1145-1154.

Honjo, S., 1977. Biogenic carbonate particles in the ocean; do they dissolve in the water column?. In: Malahoff, A. (Ed.), The Fate of Fossil Fuel $\mathrm{CO}_{2}$ in the Oceans. Plenum Press, New York and London, pp. 269-294.

Honjo, S., Manganini, S.J., Krishfield, R.A., Francois, R., 2008. Particulate organic carbon fluxes to the ocean interior and factors controlling the biological pump: a synthesis of global sediment trap programs since 1983. Prog. Oceanogr. $76,217-285$.
Huang, Y., Dupont, L., Sarnthein, M., Hayes, J.M., Eglinton, G., 2000. Mapping of C4 plant input from North West Africa into North East Atlantic sediments. Geochim. Cosmochim. Acta 64, 3505-3513.

Jickells, T., 1995. Atmospheric inputs of metals and nutrients to the oceans: their magnitude and effects. Mar. Chem. 48, 199-214.

Jickells, T.D., An, Z.S., Andersen, K.K., Baker, A.R., Bergametti, G., Brooks, N., Cao, J.J., Boyd, P.W., Duce, R.A., Hunter, K.A., Kawahata, H., Kubilay, N., laRoche, J., Liss, P.S., Mahowald, N., Prospero, J.M., Ridgwell, A.J., Tegen, I., Torres, R., 2005 Global iron connections between desert dust, ocean biogeochemistry, and climate. Science 308, 67-71.

Johnson, L.R., 1979. Mineralogical dispersal pattern of north Atlantic deep-sea sediments with particular reference to eolian dust. Mar. Geol. 29, 335-345.

Jung, M., Ilmberger, J., Mangini, A., Emeis, K.-C., 1997. Why some Mediterranean sapropels survived burn-down (and others did not). Mar. Chem. 141, 51-60.

Kasten, S., Haese, R.R., Zabel, M., Ruhlemann, C., Schulz, H.D., 2001. Barium peaks at glacial terminations in sediments of the equatorial Atlantic Ocean - relicts of deglacial productivity pulses? Chem. Geol. 175, 635-651.

Klein, B., Siedler, G., 1989. On the origin of the Azores Current. J. of Geophys. Res. 94, 6159-6168.

Klump, J., Hebbeln, D., Wefer, G., 2000. The impact of sediment provenance on barium-based productivity estimates. Mar. Geol. 169, 259-271.

Klump, J., Hebbeln, D., Wefer, G., 2001. High concentrations of biogenic barium in Pacific sediments after termination I - a signal of changes in productivity and deep water chemistry. Mar. Geol. 177, 1-11.

Knoll, M., Hernandez-Guerra, A., Lenz, B., Lopez Laatzen, F., Machin, F., Muller, T.J., Siedler, G., 2002. The eastern boundary current system between the Canary Islands and the African coast. Deep Sea Res. Part II: Top. Studies Oceanogr. 49, 3427-3440.

Koopmann, B., 1981. Sedimentation von Saharastaub im subtropischen Nordatlantik während der letzten 25.000 Jahre. Meteorol. Forschungsergebnisse 35 23-59.

Kuhlmann, H., 2004. Reconstruction of the sedimentary history offshore NW Africa: application of core-logging tools. PhD Thesis; University of Bremen.

Kuhlmann, H., Meggers, H., Freudenthal, T., Wefer, G., 2004. The transition of the monsoonal and the $\mathrm{N}$ Atlantic climate system off NW Africa during the Holocene. Geophys. Res. Lett. 31, L22204, http://dx.doi.org/10.1029/ 2004GL021267.

Kuss, J., Kremling, K., 1999. Spatial variability of particle associated trace elements in near-surface waters of the North Atlantic (30[deg]N/60[deg]W to 60[deg] $\mathrm{N} / 2$ [deg]W), derived by large volume sampling. Mar. Chem. 68, 71-86.

Martin, J.-M., Meybeck, M., 1979. Elemental mass-balance of material carried by major world rivers. Mar. Chem. 7, 173-206.

Martinez, P., Bertrand, P., Shimmield, G.B., Cochrane, Karen, Jorissen, F.J., Foster, J. Dignan, M., 1999. Upwelling intensity and ocean productivity changes off Cape Blanc (northwest Africa) during the last 70,000 years: geochemical and micropalaeontological evidence. Mar. Geol. 158, 57-74.

Matthewson, A.P.S., Kroon, G.B., Fallick, A. E., D., 1995. A 300 kyr high-resolution aridity record of the North African continent. Paleoceanography 10,677-692.

Meggers, H., Babero-Munoz, L., Barrera, C., Bergenthal, M., Betancort, J., Cardona, L. Cianca, A., Cire, B.A., Dimmler, W., Drünert, F., Eberwein, A., Freudenthal, T., Garming, L., Gebhardt, C., Gutt, J., Kahl, G., Kasten, S., Klar, S., Kopiske, E., Koy, U., Makaoui, A., Meinecke, G., Nowald, N., Pinck, A., Plewa, K., Ratmeyer, V., Romero, O., Rosiak, U., Ruhland, G., Schmidt, W., Scholz, M., Truscheit, T., Villagarcia M.G., Warnken, C., Wülbers, A., 2003. Report and preliminary results of METEOR Cruise M53/1, Limassol - Las Palmas - Mindelo, 30.03.2002-03.05.2002. Berichte Fachbereich Geowissenschaften 214, 81. Universität Bremen, Bremen.

Meggers, H., Bergenthal, M., Freudenthal, T., Hamady, B., Held, M., Hofmann, D. Kuhlmann, H., Nowald, N., Ratmeyer, V., Zizah, S., 2001. Report and preliminary results of POSEIDON Cruise PO 272, Las Palmas - Las Palmas, 01.04.200114.04.2001. Berichte Fachbereich Geowissenschaften 197, 19. Universität Bremen, Bremen.

Meggers, H., Freudenthal, T., Nave, S., Targarona, J., Abrantes, F., Helmke, P., 2002 Assessment of geochemical and micropaleontological sedimentary parameters as proxies of surface water properties in the Canary Islands region. Deep Sea Res. Part II: Top. Studies Oceanogr. 49, 3631-3654.

Meinecke, G., Barrera, C., Buhmann, S., Diaz Hidalgo, R., Fadel, R., Klar, S., Koester, J. Renken, J., Tattermusch, R., Ruhland, G., Villagarcia, M., 2005. Report and preliminary results of Poseidon Cruise 310, Las Palmas - Las Palmas, 12.04. 26.04.2004. Berichte, Fachbereich Geowissenschaften 232, 49. Universität Bremen, Bremen.

Meyers, P.A., 1994. Preservation of source identification of sedimentary organic matter during and after deposition. Chem. Geol. 144, 289-302.

Meinecke, G., Bergenthal, M., Begler, C., Ciancar, A., Klar, S., Kopiske, E., Marotto, L. Pink, A., Ruhland, G., Villagarcia, M., Tattermusch, R., 2003. Report and preliminary results of Poseidon Cruise 305, Las Palmas - Lisbon, 28.10. 06.11.2003. Berichte, Fachbereich Geowissenschaften 236, 43. Universität Bremen, Bremen.

Milliman, J.D., 1993. Production and accumulation of calcium carbonate in the ocean: Budget of a nonsteady state. Global Biogeochem. Cycles 7, 927-957.

Milliman, J.D., Meade, R.H., 1983. World-wide delivery of river sediment to the oceans. J. Geol. 91, 1-21.

Milliman, J.D., Syvitski, J.P.M., 1992. Geomorphic/Tectonic control of sediment discharge to the ocean: the importance of small mountainous rivers. J. Geol. $100,520-540$.

Mittelstaedt, E., 1991. The ocean boundary along the northwest African coast: circulation and oceanographic properties at the sea surface. Prog. Oceanogr. 26, 307-355. 
Mittelstaedt, E., Pillsbury, D., Smith, R.L., 1975. Flow patterns in the Northwest African upwelling area. Deutsche Hydrographische Zeitschrift 28, 145-167.

Moreno, A., Nave, S., Kuhlmann, H., Canals, M., Targarona, J., Freudenthal, T., Abrantes, F., 2002. Productivity response in the North Canary Basin to climate changes during the last 250000 yr: a multi-proxy approach. Earth Planet. Sci. Lett. 196, 147-159.

Müller, P.J., 1977. C/N ratios in Pacific deep-sea sediments: Effect of inorganic ammonium and organic nitrogen compounds sorbed by clays. Geochim. Cosmochim. Acta 41, 765-776.

Müller, P.J., Suess, E., 1979. Productivity, sedimentation rate, and sedimentary organic matter in the oceans - I. Organic carbon preservation. Deep Sea Res. Part A. Oceanogr. Res. Pap. 26, 1347-1362.

Neuer, S., Alfke, R., Bergenthal, M., Bittkau, A., Böhme, L., Bothmer, H., Cianca, A. Diekamp, V., Freudenthal, T., Gerdes, A., Godoy, J., Grimm, G., Hayn, C., Hebbeln, D., Huebner, $\mathrm{H}$, Kahl, $\mathrm{G}$, Klein, T, Köster, J., Laglera, L, Langer, J, Lenz, B. Meggers, H., Meinecke, G., Metzler, W., Moroto, L., Nave, S., Ochsenhirt, W.-T., Ratmeyer, V., Rosiak, U., Rueda, M.J., Ruhland, G., Schiebel, R., Schüßler, U. Struck, U., Themann, S., Villagarcia, M.G., von Oppen, C., Waldmann, C., 2000. Report and preliminary results of METEOR Cruise M 45/5, Bremen - Las Palmas, 01.10.1999-03.11.1999. Berichte Fachbereich Geowissenschaften 163, 93. Universität Bremen, Bremen.

Neuer, S., Freudenthal, T., Davenport, R., Llinas, O., Rueda, M.-J., 2002. Seasonality of surface water properties and particle flux along a productivity gradient off NW Africa. Deep Sea Res. Part II: Top. Studies Oceanogr. 49, 3561-3576.

Neuer, S., participants, a. c., 1997. Report and prelimininary results of VICTOR HENSEN Cruise 96/1, Las Palmas - Las Palmas, 10.01.1996-04.03.1996. Berichte Fachbereich Geowissenschaften 96, 76. Universität Bremen, Bremen.

Neuer, S., Ratmeyer, V., Davenport, R., Fischer, G., Wefer, G., 1997. Deep water particle flux in the Canary Island region: seasonal trends in relation to long-term satellite derived pigment data and lateral sources. Deep Sea Res. Part I: Oceanogr. Res. Pap. 44, 1451-1466.

Nicholson, S.E., 2000. The nature of rainfall variability over Africa on time scales of decades to millenia. Global Planet. Change 26, 137-158.

Nürnberg, C.C., Bohrmann, G., Schlüter, M., Frank, M., 1997. Barium accumulation in the Atlantic sector of the Southern Ocean: results from 190,000-year records. Paleoceanography $12,594-603$.

Nykjær, L., Van Camp, L., 1994. Seasonal and interannual variability of coastal upwelling along northwest Africa and Portugal from 1981 to 1991. J. Geophys. Res. 99, 14,197-114,207.

Paytan, A., Kastner, M., Chavez, F., 1996. Glacial to interglacial fluctuations in productivity in the equatorial Pacific as indicated by marine barite. Science $274,1355-1357$.

Peterson, M.N.A., 1966. Calcite: rate of dissolution in a vertical profile in the Central Pacific. Science 154, 1542-1544.

Petschick, R., Kuhn, G., Gingele, F., 1996. Clay mineral distribution in surface sediments of the South Atlantic: sources, transport, and relation to oceanography. Mar. Geol. 130, 203-229.

Pfeifer, K., Hensen, C., Adler, M., Wenzhfer, F., Weber, B., Schulz, H.D., 2002. Modeling of subsurface calcite dissolution, including the respiration and reoxidation processes of marine sediments in the region of equatorial upwelling off Gabon. Geochim. Cosmochim. Acta 66, 4247-4259.

Pfeifer, K., Kasten, S., Hensen, C., Schulz, H.D., 2001. Reconstruction of primary productivity from the barium contents in surface sediments of the South Atlantic Ocean. Mar. Geol. 177, 13-24.

Plewa, K., Meggers, H., and Kasten, S., 2006. Barium in sediments off northwest Africa: a tracer for paleoproductivity or meltwater events? Paleoceanography 21. PA 2015, 10.1029/2005PA001136.

Rea, D.K., 1994. The paleoclimatic record provided by Eolian deposition in the deep sea: the geologic history of wind. Rev. Geophys. 32 (2), 159-195.

Reichart, G.J., den Dulk, M., Visser, H.J., van der Weijden, C.H., Zachariasse, W.J., 1997. A $225 \mathrm{kyr}$ record of dust supply, paleoproductivity and the oxygen minimum zone from the Murray Ridge (northern Arabian Sea). Palaeogeogr. Palaeoclimatol. Palaeoecol. 134, 149-169.

Reitz, A., Pfeifer, K., de Lange, G.J., Klump, J., 2004. Biogenic barium and the detrita $\mathrm{Ba} / \mathrm{Al}$ ratio: a comparison of their direct and indirect determination. Mar. Geol. 204, 289-300.

Rösler, H.J., Lange, H., 1972. Geochemical Tables. Elsevier, New York 468 pp.

Ruhland, G., Barrera, C., Dehning, K., Klar, S., Kopiske, E., Koester, J., Martinez Garcia V., Moehlmann, M., Villagarcia, M., Wynar, J.B., 2005. Report and preliminary results of Poseidon Cruise 319, Las Palmas - Las Palmas, 06.12.-17.12.2004. Berichte Fachbereich Geowissenschaften 237, 50. Universität Bremen, Bremen.

Sall, J., Creighton, L., Lehman, A., 2005, JMP Start Statistics: A Guide to Statistics and Data Analysis Using JMP, 3rd edn, 560 pp., Curt Hinrichs, Cary, NC $27513-$ 2414, USA.

Sarnthein, M., Koopmann, B., 1980. Late Quaternary deep-sea record on northwes African dust supply and wind circulation. Palaeoecol. Africa 12, 239-253.

Sarnthein, M., Thiede, J., Pflaumann, U., Erlenkeuser, H., Fütterer, D.K., Koopmann, B., Lange, H., Seibold, E., 1982. Atmospheric and oceanic circulation patterns off Northwest Africa during the past 25 million years. In: Seibold, E. (Ed.) Geology of The Northwest African Continental Margin. Springer-Verlag, Berlin, pp. 545-604.

Schefuß, E., Ratmeyer, V., Stuut, J.-B.W., Jansen, J.H.F., Sinninghe Damste, J.S., 2003. Carbon isotope analyses of $n$-alkanes in dust from the lower atmosphere over the central eastern Atlantic. Geochim. Cosmochim. Acta 67, 1757-1767.
Schemainda, R., Nehring, D., Schulz, S., 1975. Ozeanologische Untersuchungen zum Produktionspotential der nordwestafrikanischen Wasserauftriebsregion 1970-1973. Geodätische und geophysikalische Veröffentlichungen 4, 1-88.

Schneider, R.R., Price, B., Müller, P.J., Kroon, D., Alexander, I., 1997. Monsoon related variations in Zaire (Congo) sediment load and influence of fluvial silicate supply on marine productivity in the east equatorial Atlantic during the last 200,000 years. Paleoceanography 12, 463-482.

Schütz, L., Rahn, K.A., 1982. Trace-element concentrations in erodible soils. Atmos. Environ 1967 (16), 171-176.

Shimmield, G.B., 1992. Can sediment geochemistry record changes in coastal upwelling paleoproductivity? Evidence from northwest Africa and Arabian Sea. In: Emeis, K.C. (Ed.), Upwelling Systems: Evolution Since the Early Miocene. Geological Society of London, London, pp. 29-46.

Sirocko, F., Garbe-Schonberg, D., Devey, C., 2000. Processes controlling trace element geochemistry of Arabian Sea sediments during the last 25,000 years. Global Planet. Change 26, 217-303.

Stein, R., 1991. Accumulation of organic carbon in marine sediments, Results from the Deep Sea Drilling Project/Ocean Drilling Program. Springer-Verlag, Berlin $217 \mathrm{pp}$.

Stramma, L., Siedler, G., 1988. Seasonal changes in the North Atlantic subtropical Gyre. J. Geophys. Res. 93, 8111-8118

Strub, P.T., Kosro, P.M., Huyer, A., 1991. The nature of the cold filaments in the California current system. J. Geophys. Res. 96, 14743-14768.

Stuut, J.-B., Zabel, M., Ratmeyer, V., Helmke, P., Schefuß, E., 2005. Provenance of present-day eolian dust collected off NW Africa. J. Geophys. Res., 110 http://dx.doi.org/10.1029/2004JD005161.

Summerhayes, C.P., Milliman, J.D., Briggs, S.R., Bee, A.G., Hogan, C., 1976. Northwest African shelf sediments: influence of climate and sedimentary processes. J. Geol. 84, 277-300.

Taylor, S.R., 1964. Abundance of chemical elements in the continental crust: a new table. Geochim. Cosmochim. Acta 28, 1273-1285.

Taylor, S.R., McLennan, S., 1995. The geochemical evolution of the continental crust. Rev. Geophys. 33, 241-265.

Thompson, E.I., Schmitz, B., 1997. Barium and the late Paleocene $\delta^{13} \mathrm{C}$ maximum: evidence of increased marine surface productivity. Paleoceanography 12, 239-254.

Torres-Padrón, M.E., Gelado-Caballero, M.D., Collado-Sánchez, C., Siruela-Matos, V.F., Cardona-Castellano, P.J., Hernández-Brito, J.J., 2002. Variability of dust inputs to the CANIGO zone. Deep Sea Res. Part II: Top. Studies Oceanogr. 49, 3455-3464.

Turekian, K.K., Wedepohl, K.H., 1961. Distribution of the elements in some major units of the Earth's crust. Geol. Soc. Am. Bull. 72, 175-192.

Tyson, R.V., 1995. Sedimentary organic matter, Organic Facies and Palynofacies. Chapman \& Hall, London, pp. 615.

Tyson, R.V., 2001. Sedimentation rate, dilution, preservation and total organic carbon: some results of a modelling study. Org. Geochem. 32, 333-339.

Van Camp, L., Nykjaer, L., Mittelstaedt, E., Schlittenhardt, P., 1991. Upwelling and boundary circulation off Northwest Africa as depicted by infrared and visible satellite observations. Prog. Oceanogr. 26, 357-402.

Vinogradov, A.P., 1962. Average contents of chemical elements in the principal types of igneous rocks of the Earth's crust. Geokhimiya 7, 641-664.

Volbers, A.N.A., Henrich, R., 2002. Late Quaternary variations in calcium carbonate preservation of deep-sea sediments in the northern Cape Basin: results from a multiproxy approach. Mar. Geol. 180, 203-220.

Von Breymann, M.T.K., Emeis, K.C., Suess, E., 1992. Water depth and diagenetic constraints on the use of barium as a paleoproductivity indicator. In: Emeis, K.C. (Ed.), Upwelling Systems: Evolution since the Early Miocene. Geological Society Special Publication, London, pp. 273-284.

Wagner, T., Dupont, L.M., 1999. Terrestrial organic matter in marine sediments: analytical approaches and eolian-marine records in the Central Equatorial Atlantic. In: G., W. (Ed.), Use of Proxies in Paleoceanography: Examples from the South Atlantic. Springer-Verlag, Berlin, Heidelberg, pp. 547-574.

Weaver, P.P.E., Wynn, R.B., Kenyon, N.H., Evans, J., 2000. Continental margin sedimentation, with special reference to the north-east Atlantic margin. Sedimentology 47, 239-256.

Wedepohl, K.H., 1971. Environmental influences on the chemical composition of shales and clays. In: Urey, H.C. (Ed.), Physics and Chemistry of the Earth. Pergamon, Oxford, pp. 307-331.

Wedepohl, K.H., 1995. The composition of the continental crust. Geochim. Cosmochim. Acta 59, 1217-1232.

Wefer, G., Abrantes, F., Bassek, D., Bollman, J., Bozzano, G., Diekamp, V., Dittert, L. Eberwein, A., Klump, J., Kuhlmann, H., Lindblom, S., Meggers, H., Meinecke, G., Metzler, W., Moustafa, Y., Peters, M., Ratmeyer, V., Rieß, W., Rosiak, U., Segl, M., Skoglund, S., Targarona, J., Vaqueiro, S., Waldmann, C., Wenzhöfer, F., Zabel, M. 1997. Report and preliminary results of METEOR Cruise M 37/1, Lisbon - Las Palmas, 04.12.1996-23.12.1996. Berichte Fachbereich Geowissenschaften 90, 79. Universität Bremen, Bremen.

Wefer, G., Segl, M., Buhlmann, K., Bassek, D., Deeken, A., Dehning, K., Diekamp, V., Drünert, F., Eberwein, A., Franke, P., Freudenthal, T., Godoy, J., Geisen, M. González-Dávila, M., Günther, L., Hayn, C., Henderiks, J., Jeronimo, D., Kotte, N., Koy, U., Kretzschmar, K., Langer, J., Makaoui, A., Maroto, L., Meggers, H., Meinecke, G., Metzler, W., Moreno, A., Neuer, S., Ratmeyer, V., Schroeter, M., Sprengel, C., Targarona, J., Thiele, J., Thierstein, H.R., von Oppen, C., Waldmann, C., 1998. Report and preliminary results of METEOR Cruise M 42/4, Las Palmas - Las Palmas - Viena do Casstelo, 26.09.98-26.10.1998. Berichte Fachbereich Geowissenschaften 132, 104. Universität Bremen, Bremen. 
Wien, K., Holz, C., Kolling, M., Schulz, H.D., 2006. Age models for pelagites and turbidites from the Cap Timiris Canyon off Mauritania. Mar. Pet. Geol. 23, 337-352.

Wien, K., Wissmann, D., Kölling, M., Schulz, H.D., 2005. Fast application of X-ray fluorescence spectrometry aboard ship: how good is the portable new Spectro Xepos analyser? Geo-Mar. Lett. 25, 248-264.

Windom, H.L., 1975. Eolian contributions to marine sediments. J. Sediment. Petrol. 45, 1975.

Wynn, R.B., Masson, D.G., Stow, D.A.v., Weaver, P.P. e., 2000. The Northwest African slope apron: a modern analogue for deep-water systems with complex seafloor topography. Mar. Pet. Geol. 17, 253-265.

Yarincik, K.M., Murray, R.W., Peterson, L.C., 2000. Climatically sensitive eolian and hemipelagic deposition in the Cariaco Basin, Venezuela, over the past 578,000 years: results from Al/Ti and K/Al. Paleoceanography 15, 210-228.
Zabel, M., Bickert, T., Dittert, L., Haese, R.R., 1999. Significance of the sedimentary $\mathrm{Al}$ :Ti ratio as an indicator for variations in the circulation patterns of the equatorial Atlantic. Paleoceanography 14, 789-799.

Zabel, M., Schneider, R.R., Wagner, T., Adegbie, A.T., de Vries, U., Kolonic, S., 2001. Late quaternary climate changes in central Africa as inferred from terrigenous input to the niger fan. Quat. Res. 56, 207-217.

Zonneveld, K.A.F., Versteegh, G.J.M., Kasten, S., Eglinton, T.I., Emeis, K.-C., Huguet, C., Koch, B.P., de Lange, G.J., de Leeuw, J.W., Middelburg, J.J., Mollenhauer, G., Prahl, F.G., Rethemeyer, J., Wakeham, S.G., 2010. Selective preservation of organic matter in marine environments; processes and impact on the sedimentary record. Biogeosciences 7, 483-511. 